

\section{Pinal Roport}

\section{AIRPHONO DIMSRPRETATTON OP BNOTEBRDE SOTHS OP NOBIB COUNIY, DDIUU}

20:

z. B. Woods, DAroctor

Joint Highey Besearch Project

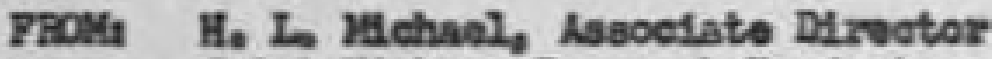

Joint Highney Basearch Project
Decuaber 14,1962

Fiet $2-5-2-36$

Projectt $c-36-513$

The atteched ruport entitiled "Mirphoto Interprotatsoa of Bngineering Solls of lloble County, Indiana", corplotes a portion of the projert concerned idth onelinoerling ooflis mapping rrom aorlal photographs. The roport

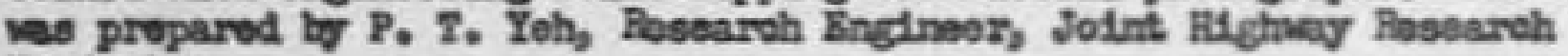
Projeot.

Tha solls mapping of Hoble County vee done primurlly by afrphoto interpretation. To inorease the value of the oounty ao12 mape, the major so11 types wore saupled and taste vere oonduoted in the sodils laborutorg. The soll tests parforrad inoludo grain-ulso annlysis,

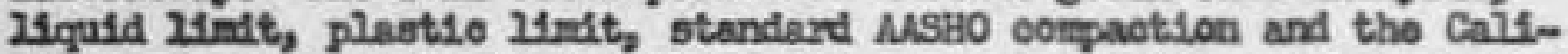
fornis Boaring ratio tost. The solls wore claselfled ualing both the

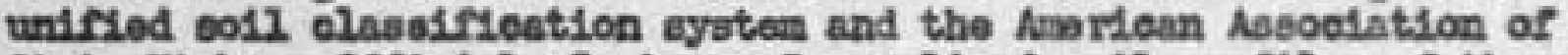
State Highwey Orfiolels Syutem, Genoraltsed soll prorilos of the major ooll groupe vero Included on the soll map. An osalid print of the onglnooring e01ls mep and a suamary tablo of the enclneoring teat data aro Inoluded in the roport.

Respectrully subadtiod,

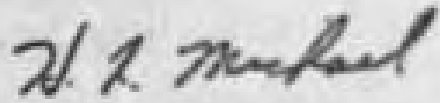

H. Is Heheal

Asoocinte Dirootor

HII $/ 1$ loo

Attachonits

Copt Y. In Labbuacher

J. 2. Cooper

W. I. Dolah

W. H. Coots

F. P. Havoy

F. S. แมบ

O. A. Ieonarda

J. 7. Voteughlen

R. D, 2608
R. B. 1621s

I., B. Soott

J. V. Sarthe

J. In thiling

B. J. Ioder 


\section{Pinal Boport}

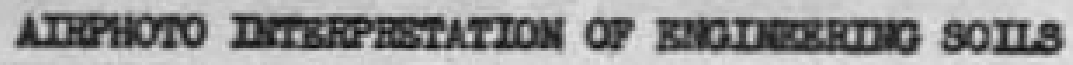 \\ a \\ woscs coviar, Doruu}

\section{奵}

P. F. Yoh

Revearch Inginear

Joint Highnery Researeh Project

Fiva: 1-5-2-36

Project: c-36-5uB

Purtue University

Iafagotte, Indiana

Decesbos 14,1962 


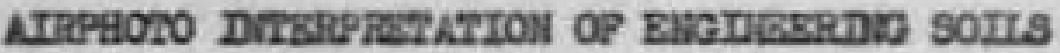

\author{
OP

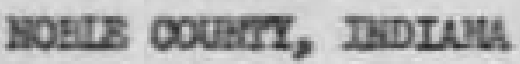 \\ by \\ P. 2. Yoh
}

\section{INTEODCTZOM}

Tho englneoring solle anp of Noble County, Indiana, which

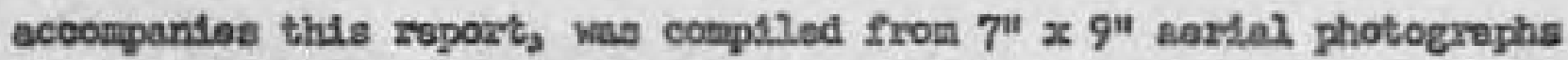
heving an approodmate acale of 1.20,000, All of the afrephotos vero taken in Ootober 1938 in conneotion with the Unitod Statos Department of Agrloultur progran and vore purohased from that ageneg.

The recossional moratnoe of the county had been mappod by Kataygooh Nishimura in his naster's theais antitled "Aisphoto Pattern Study of the Erie Iobe Becossions Xoraines in Indinna" (2). Beviations and detalls verv edded, and the romaining area of the courty vas axpped to cosplete the engtnooring sollo mp.

Photo interpietation of the land Porns and sol1 tecturva of this oounty wa accuspished in sccordance vith accopted prinotples of obearvation and inforenoe (2). Flold tilps were nade to the arva for the purposes of rosolving ambiguous dotatls, corralating alrghoto pattems with oo11 tosturos, and to socuro so12 anglos. Test data included hesoln were obtained from leboratory testing accomplishod on these earplos, Stendard mapping symbols developed by tho staff of the Airphoto Interprotation Iaboratory, School of Civ1l Inginoering, Purdue Datveralty, waro enplojod to delinaste land forms and goll textures. The tact of this report largaly ropresents an effort to overeome the

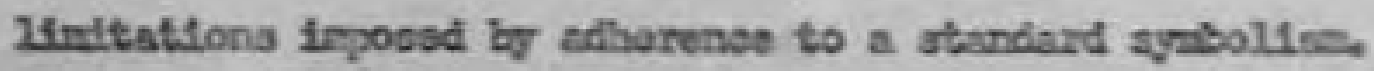



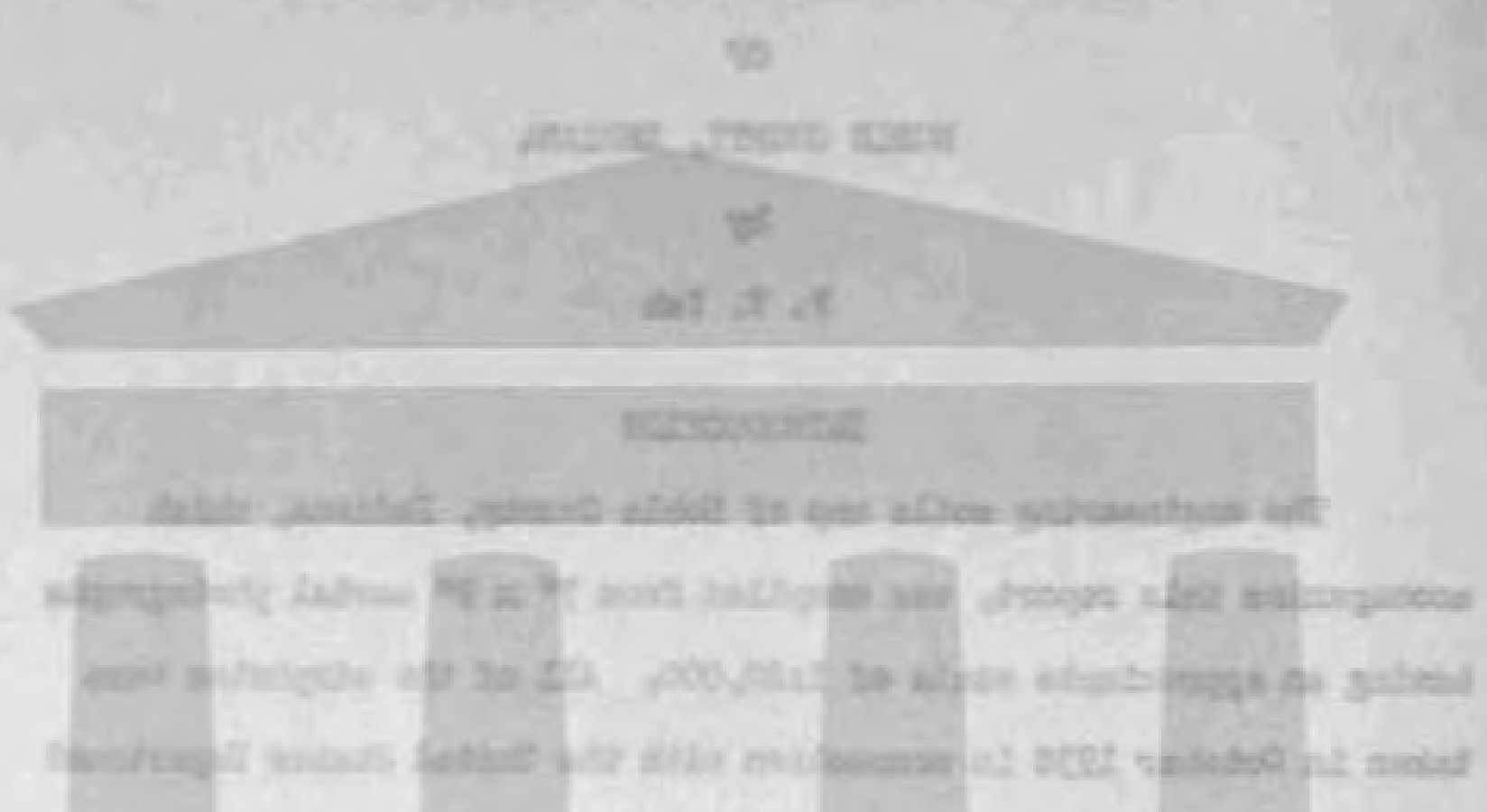

Digitized by the Internet Archive in 2011 with funding from LYRASIS members and Sloan Foundation; Indiana Department of Transportation

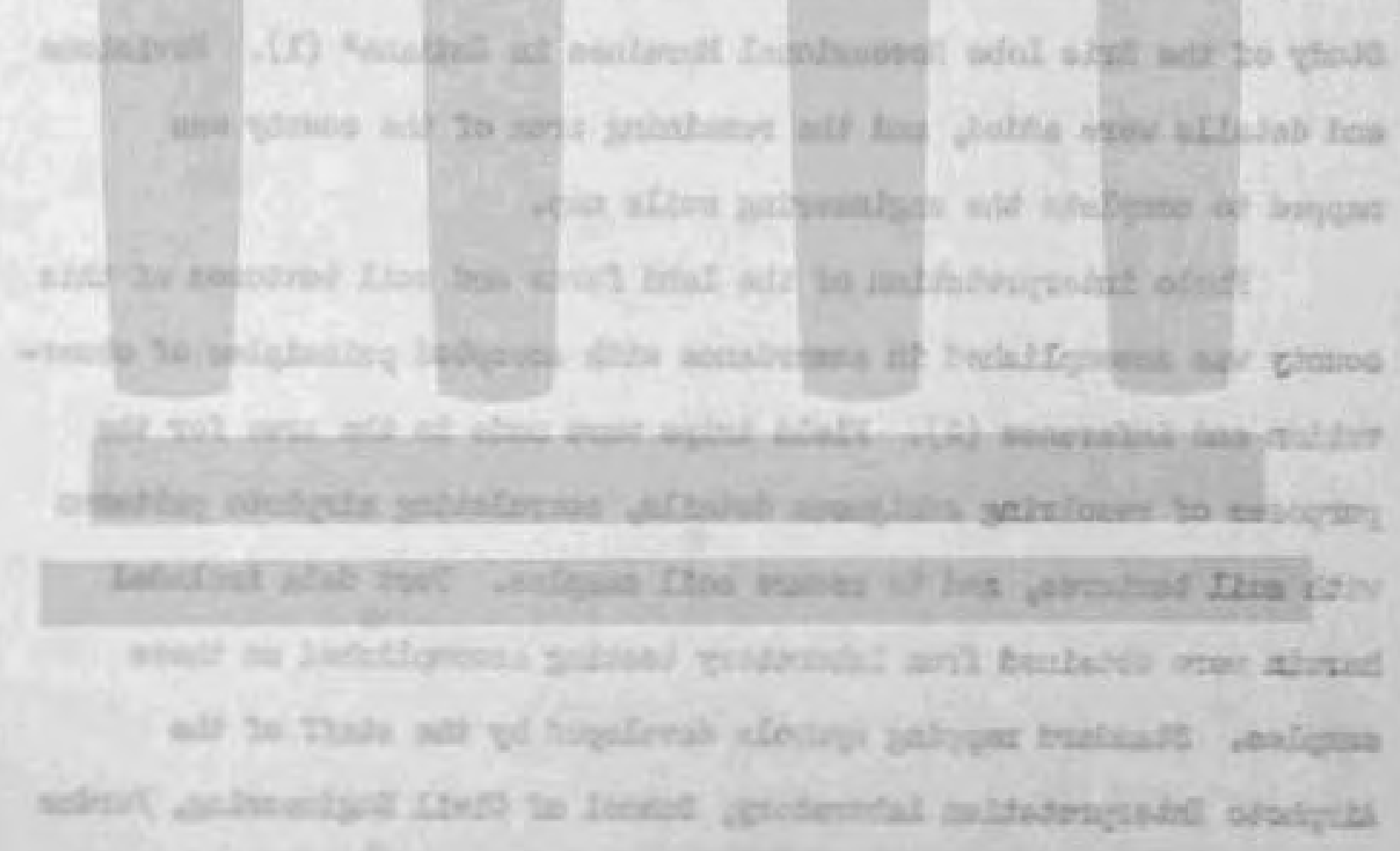


An appronoh toverde bettor ut114estion of ong1nooring a011 mape or indinas hes bean atteriptod udth the inolusion of soll proflie and Iaboratory elesedflestion for the prinoiple oollo roprosented within this oourty. Certein alls of obvioue inferlor engineering qualitios, were not seupied but were latleated on tho atteched atp. Tho profyine of those solls vorv ootplled from tho egrloulturnl 1terature. These aodis inelide prineipaily organta axterlnis such as mok, peat and highy organto soils vhich are of only lisited extent.

14bernl reference vas mede to the "Soll Surver of libble County, 1953" published by the United States Dopertiont of Agrioultare and The Forration, Distribution and Bnginaaring Charactoristice of Solls", (4) publishod by the Brginaering Byperimat. Station of Purlus Dnifersity. In mary instenees the egrioulturel solis map did provido a corvenient andorvement of the photo interpretater's Judgont.

\section{INZSRPRSTATION OE ARBA}

Genern1.

lloble County is looutod in the northeastem part of Indsana as ahowa in F13. 2. Tho county is nosxiy rootangular in shapo, with a longth of 24 thlles (enst-ivest) and a macimm wdith of 18 miles (northsouth). It coisploes an ares of 412 aquare mllos (3). Albion is the county soat located nasar the oanter of the county. A population of 28,262 inhabitento resided vdthin the county with 1325 Inhabitants roported for Nubion acoording to the 2960 consus (5). The langeat ofty In toble County is Kendellville vith a population of 6765 in 1960 (5). Aecording to the 1950 census of Agrieulture there vero 24,6,182 aores of farn land (93.8\% of the county area) in Nobls county (6). Hooded lands are scattarod throughout the county in wall patches as shorn In tho dirphoto mosale in Fig, 2. 


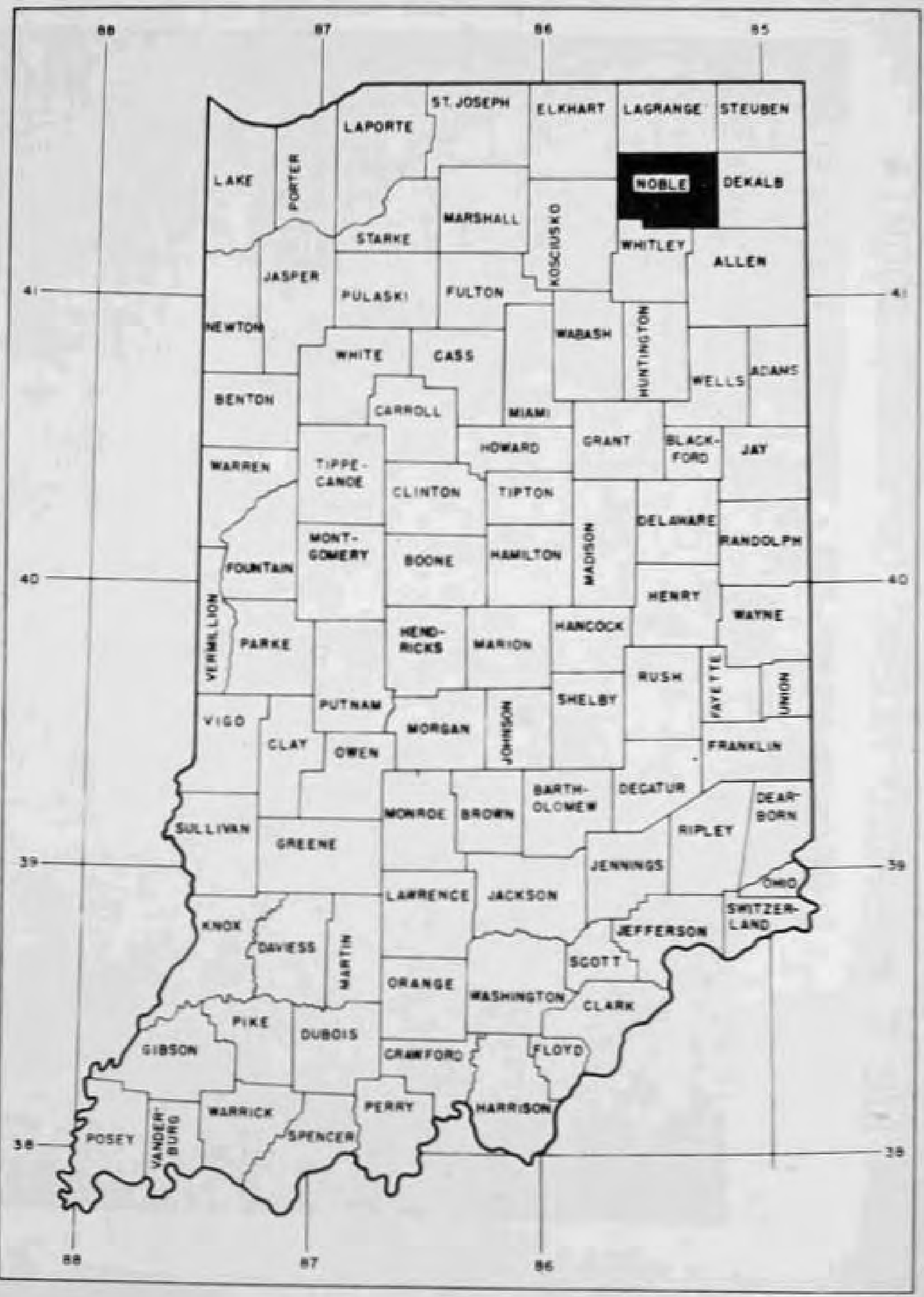

FIG. I. LOCATION MAP OF NOBLE COUNTY 


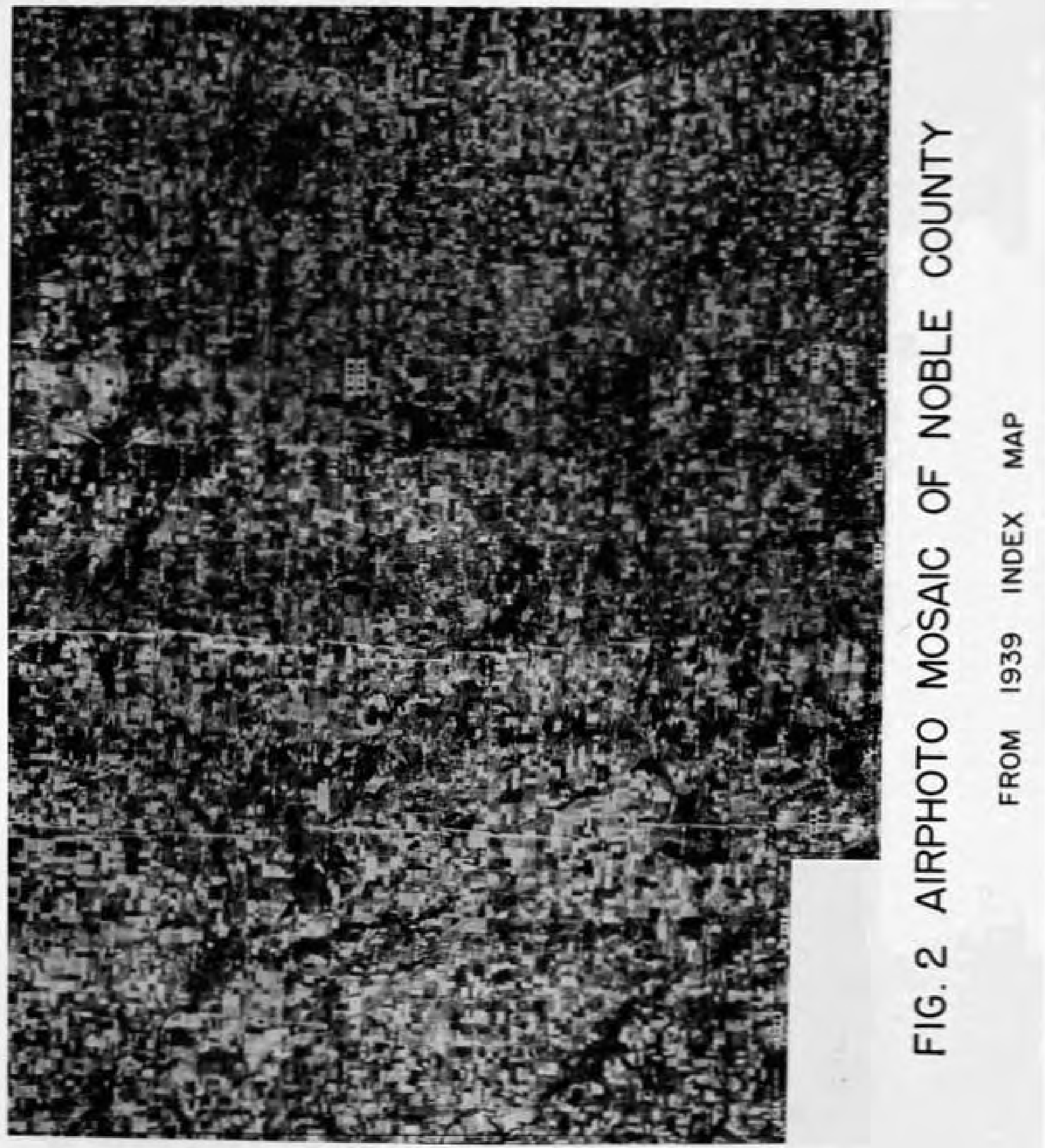




\section{Densinese Fentures}

Noble County 21es in three anjor drafnage basing of the state. Tho eastern paxt is in the Jauses, the southern part is in tho labeak and the oentrel end northern parts are in the St. Joeoph drulnuge bagin. Ths

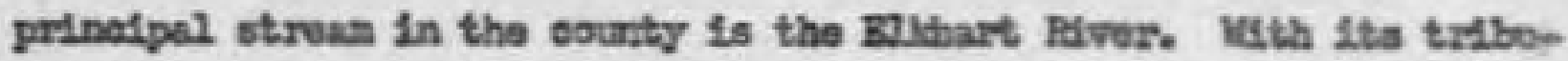
tarlos, navoly ths north branch and the south buunoh, wore then one hale of tho oounty is drainad into the St. Joeoph River to tho wost. Naturel andinage is veakly devoloped in neot of the county, eapeofinly in the northnastem quarter ahore gramilar materials are concentrated (see Fig. 3).

Thore are about 60 lnikos or ponds in Mloble County. Ibot of thas arv located along the Eajor drainnge ohannols (ese Mge 3). The largest (ebout one square adle in aroa) is nawed Sylvan Inla located east of Roem Clty. I large number of laions aro bolng repidly anavocehed upon by the grovith of equatic vegetation and aro appronehing extinoticn.

\section{cisingte.}

Noblo County hes a humid, temperate and contsinontal alimato. The varintions between vinter anci sumpor termporature aro vide, ranging from a madmin of 205 dagaves in August to a grinimm of -22 degroes in January. The avarage annual preodpitation is 32.68 inohos. The nornal conthly and the annuel traperature and prooipltation at IIblon are surmined in Tablo I (7)。

\section{Bhrolograter}

Woblo County is Included in the Stouban Vordinel Lalo Section of

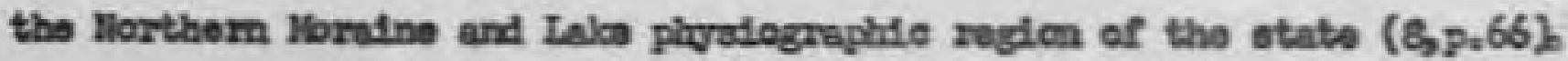




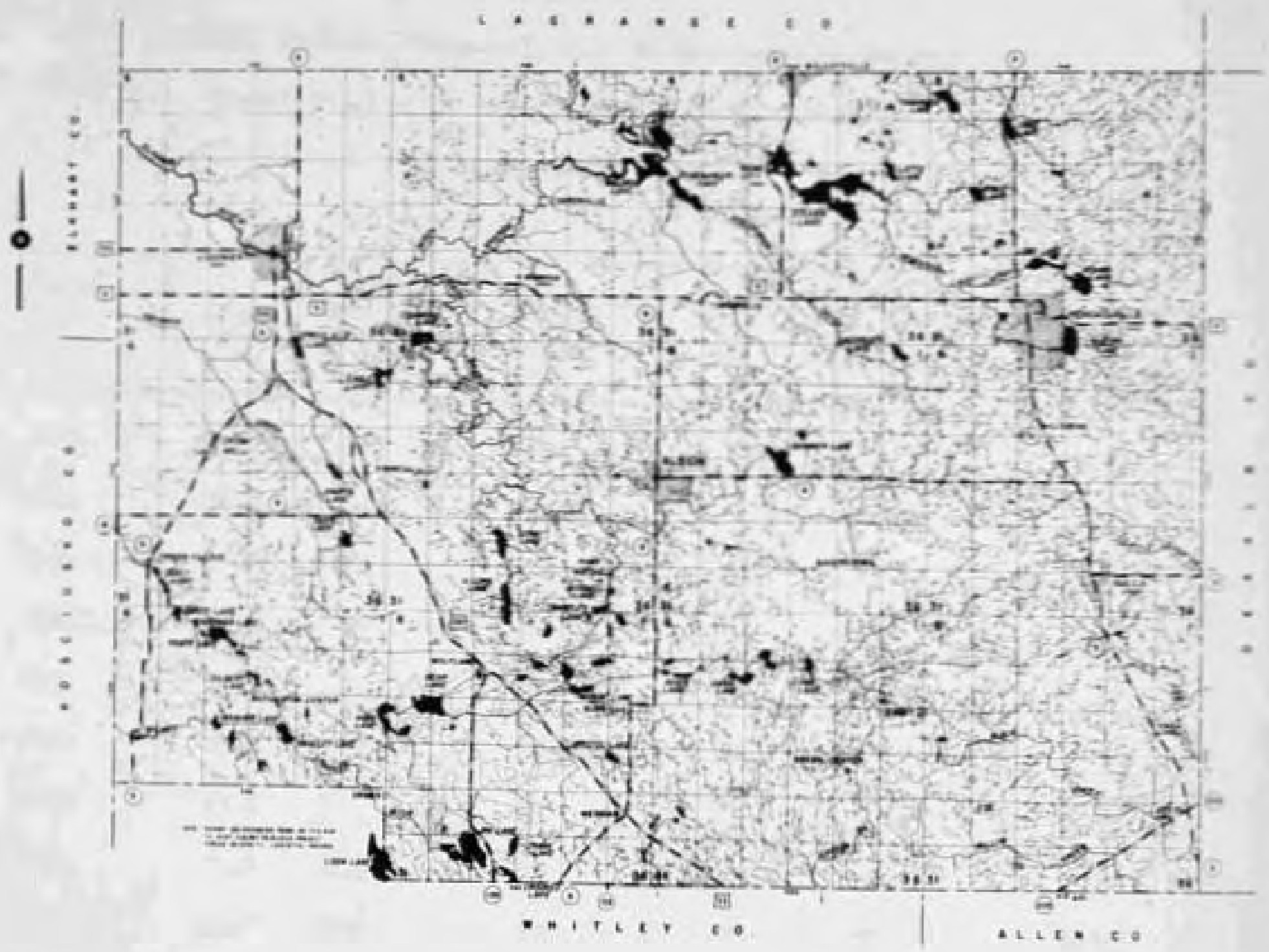

FIG. 3

DRAINAGE MAP

NOBLE COUNTY

INDIANA

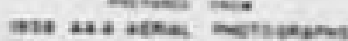

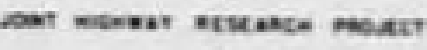

nosw wevent?

as

Tit? $=0$ 


\section{Tablo 1}

Normal Nonibly, Seasonal, and Annual Temperaturo and

Precipitation at Albion, Noble County, Indians

(Biovation 983 foet)*

\begin{tabular}{|c|c|c|c|c|c|c|}
\hline \multirow{2}{*}{ Panth } & \multicolumn{3}{|c|}{ Tegrograture. } & \multicolumn{3}{|c|}{ Prosinfintion } \\
\hline & $\frac{\text { Noan }}{\mathrm{O}_{\mathrm{F}}}$ & $\begin{array}{l}\text { Dbeolute } \\
\text { Madinum } \\
\text { op }\end{array}$ & $\begin{array}{l}\text { Absolute } \\
\text { Maninam } \\
\text { Op }\end{array}$ & $\begin{array}{l}\text { Voan } \\
\text { in. }\end{array}$ & $\begin{array}{l}\text { Tothal for tho } \\
\text { Drisest Year } \\
\text { Inohos }\end{array}$ & $\begin{array}{l}\text { Totel for tho } \\
\text { Wettost rear } \\
\text { inohos }\end{array}$ \\
\hline Jan, & 25.9 & 57 & -22 & 2.18 & 1.01 & 2.82 \\
\hline Fob。 & 26.4 & 68 & -18 & 2.55 & 0.70 & 2.67 \\
\hline $1 \mathrm{kax}$. & 35.2 & 78 & -6 & 2.32 & 2.66 & 4.55 \\
\hline Ap:HZ & 47.7 & 89 & 10 & 2.58 & 1.52 & 4.85 \\
\hline Isy & 58.8 & 94 & 22 & 3.25 & 0.92 & 1.90 \\
\hline Jume & 69.2 & 99 & 36 & 3.78 & 1.93 & 6.32 \\
\hline गैख्यु & 73.2 & 204 & 42 & 3.44 & 1.32 & 6.37 \\
\hline Aug. & 72.2 & 305 & 42 & 3.52 & 3.06 & 7.69 \\
\hline Sept. & 64.0 & 202 & 30 & 2.90 & 4092 & 1.23 \\
\hline Oct. & 52.9 & 89 & 36 & 2.92 & 0.53 & 9.52 \\
\hline Nov. & 38.5 & 75 & -3 & 2.45 & 2.89 & 2.80 \\
\hline Deco & 27.9 & 62 & -20 & 1.82 & 1.23 & 2.38 \\
\hline Annual & 49.3 & 105 & -27. & 32.68 & $\begin{array}{c}22,68 \\
(\text { In 2934) }\end{array}$ & $\begin{array}{l}50.10 \\
(\text { in } 1954)\end{array}$ \\
\hline
\end{tabular}

* The elevation of the atatsion has boen changed throughout the years from 919 feet (twil Jan, 1953) to 960 Peet than 930 soet and to the prosent 983 reet atnoo Fob. 1961. Complied from the "Mimatological Dats of Indians" on a wh-year zacosd through 1963. 
With respreot to 1ta plysiographise altuatsion in the Undtod Statos, the oounty is a prat of the Bastern Laice Section of the Contrml Lonand Provinoe (8, pp. 69.)

\section{Iopozaniny}

The terratin of Voblo Counta is doelinated by the zasalve

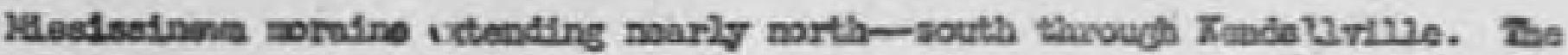

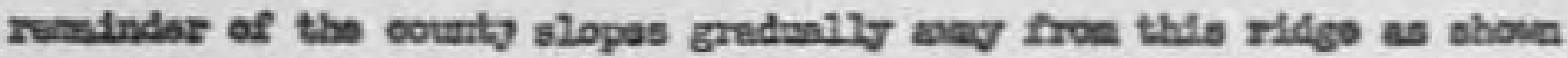
in Fig. 4. The avorage iltitude is approodsataly 990 foot abovo see lovel (8). Sand Hayl, this highert point vdthin llobls County, idth an elovation of 2070 feot abor, sas level, is looated at the northosatem cornar (Sec, 2 I35H, FUI ) or the county (9). Inother high feature is found north of DAamond Lake at Diamond Hinl about three and one-heif mloe from ISgonier. It has al elovation of 2050 foot above soe lovel and stands 11/pe a magnifioleati ialand above the Londanda (275 foet above Diamond Lako). The Iovest altitude of 84,5 feet oecurs in the valley of Willow Creek at the sot'heas'tern corner of Nloble County.

The 2tilastasineve moraine usvere the eastorn half of the county (9e0 F/g. 5). Elovation differenses on the morntne range from about 950 feot at the southem boundary to 2050 foot at the northeeat boxdor. The moraine riees from either stile by ouccesalve elovations to an undulating tablo 2nnd. The met prominant tablo land is found south of Kandnuvilo. Otber near flat lands oocur esst of Eondellvillo, about aldecy botwoen Aublon and Arille and northeast of Marring In genoral, tho mraine has a rolling to hilly topography idth etrong morainie oxproosion torard the nirthoaet varo local rellef differences

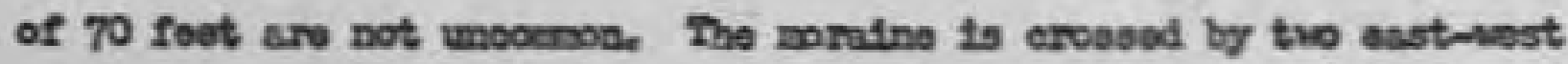




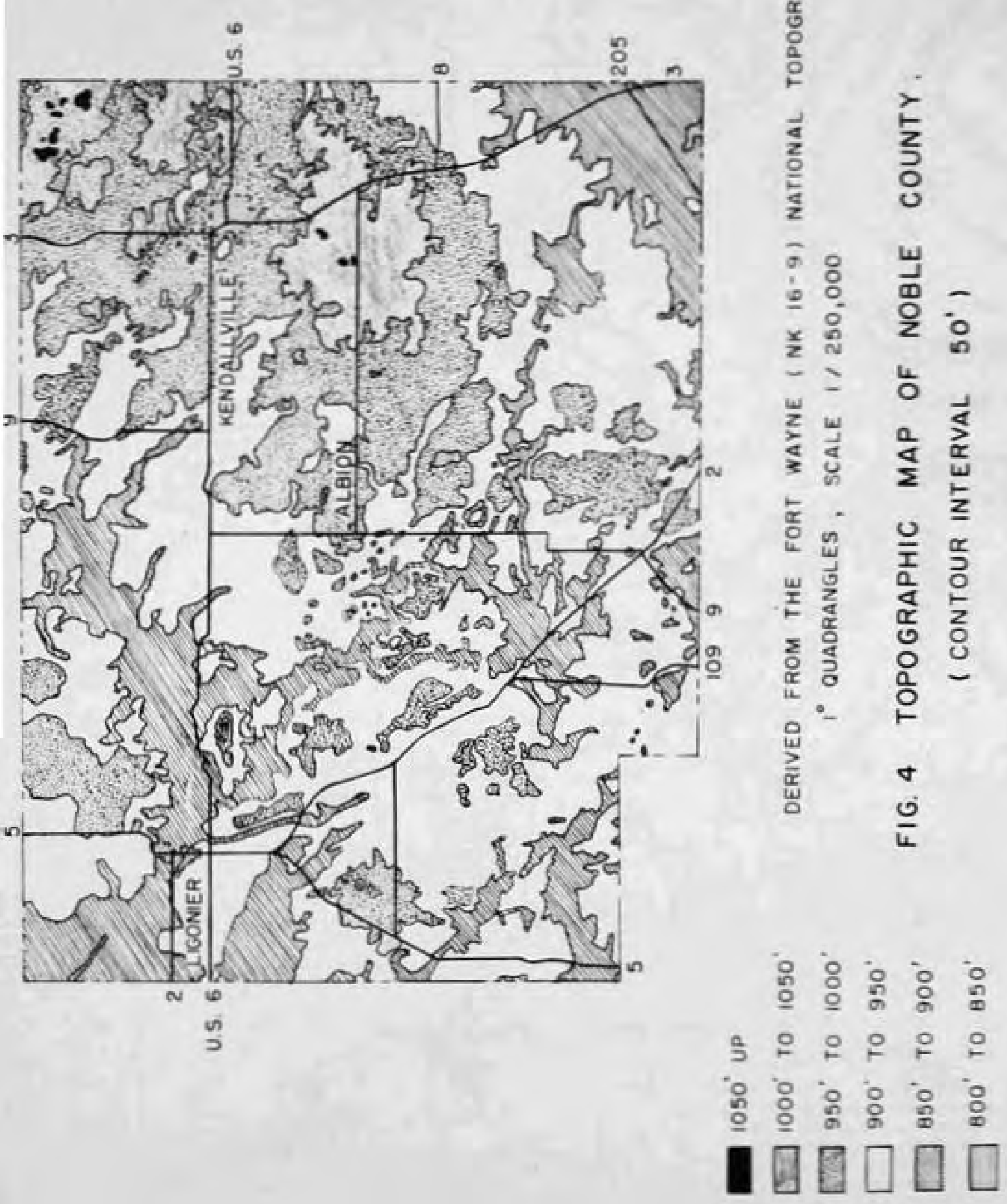




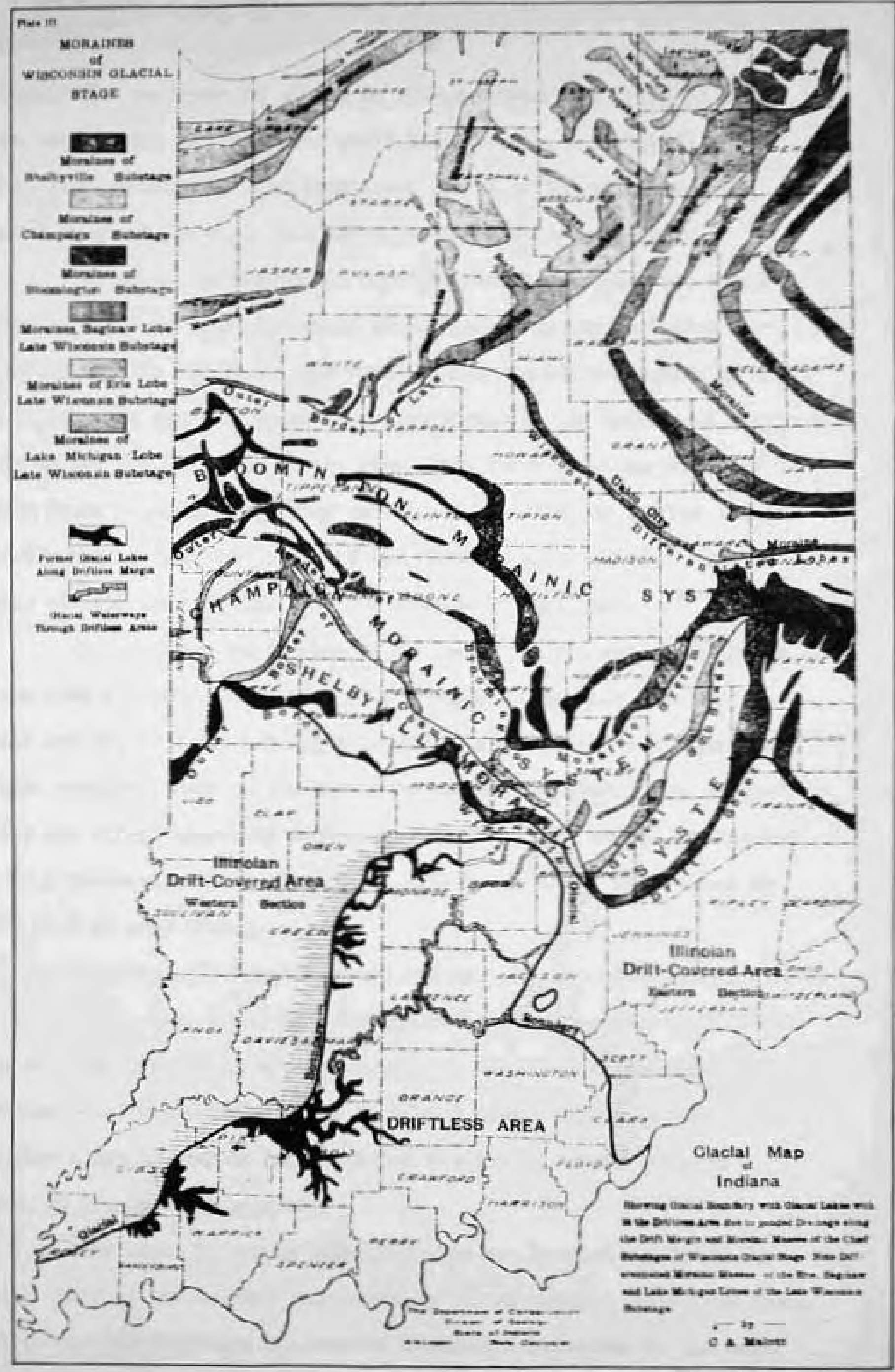

FIG. 5 GLACIAL MAP OF INDIANA 


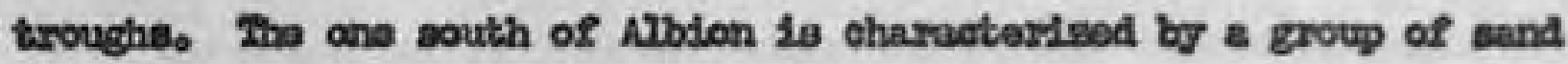
lonobs among whioh are coattered amail lalose foming a ahain(20). Tho other, Less pronounced, 11.a Irmedistely north of Kendalivillo. The onrface is about 20 to 50 seet below the surzounding uplands.

The Salnuronte moraine is loosted near the Eoutheastern cornez of the county. If is a plain that slopes gentily to the southeast (srom 2030 sto to $880 \mathrm{stb}$ ). Itte surface presents the sueceseiton of sivell and holzow. In ganeral, there is not en elevation of surflolont angritude to be ealled a hyll exoept in the area about three mlles northraet of Av121e where humock topogrephy prevatlos. The altitude in that ares is

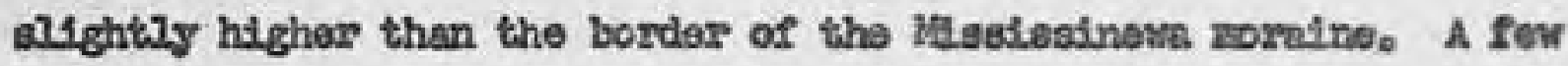
bnalls of 2050 feet in elovation axe locsted in this area,

The southwectern quexter of the county is occupied predoninately by the massive Pealcexton moreine of the Saginsu lobe (see Mg. 5). A genthy rolling or esvell and asg topography is found at the ecuthorn part of this moraine. This gentilo lendeospo changes ebrugtediy into a rugged valley and rldge topography eouthinet of Alblon. The ridges and vallegre

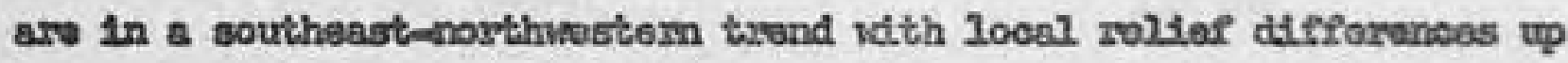
to 70 soot in mang places。

Mand 1solated moreinie areas are found in the northioctexn quarter of the county. They are surrounded of thor by outwash platins or marthes. Nany of them heve anoll and eag ropogrephys. The most rugged morrinto

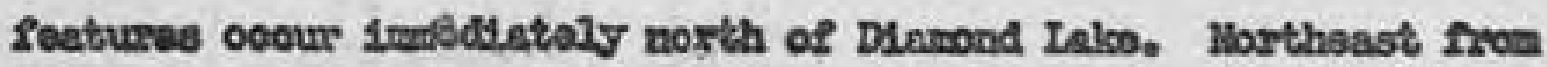

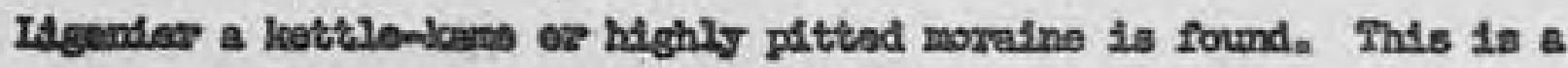
brench of the Lagrenge moratine.

Niear level or exooth outwesh plains are looated mosthy in the westesn half of the county. The Eoveraly plttod outrash plaing are found

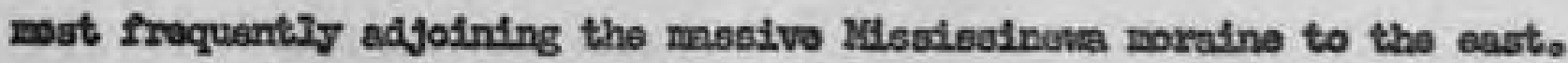




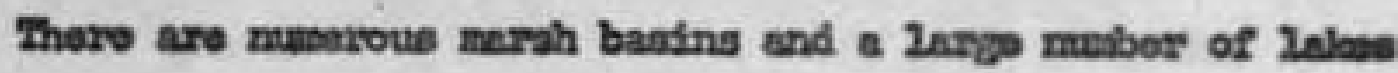
throughout the oountgy. Hoverex, the greatest ocneantration oocurs

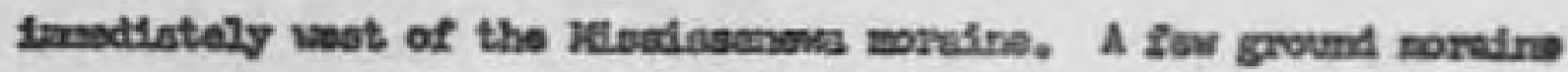
arase or till platins are found in the vestern pert of llobls Coruty.

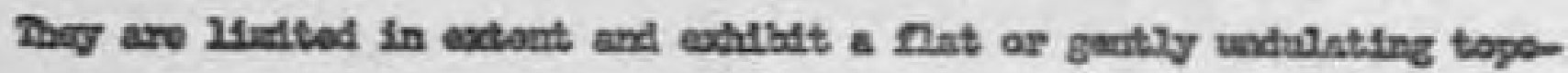
graphy.

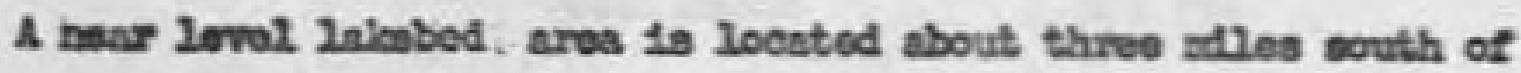
Wolf INos. It is 920 foet in elovation and is aurroundad by outhessh

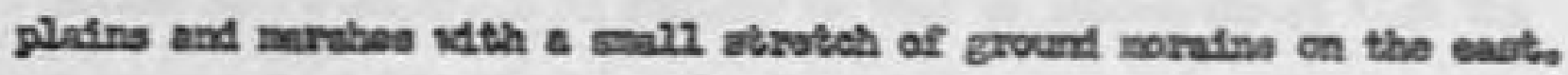

\section{Geolers}

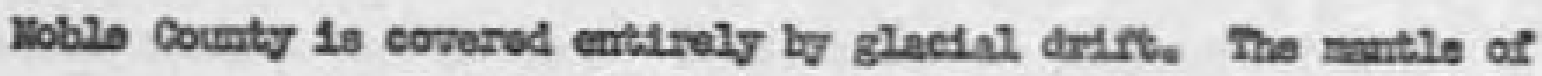
the drift is probably novhess less than 200 zoot thlak whilo upon the arest of the moralno it is nearly 500 feot (10). Borling for gas at Aublon furndahed the faulonding $\log (20)$ a

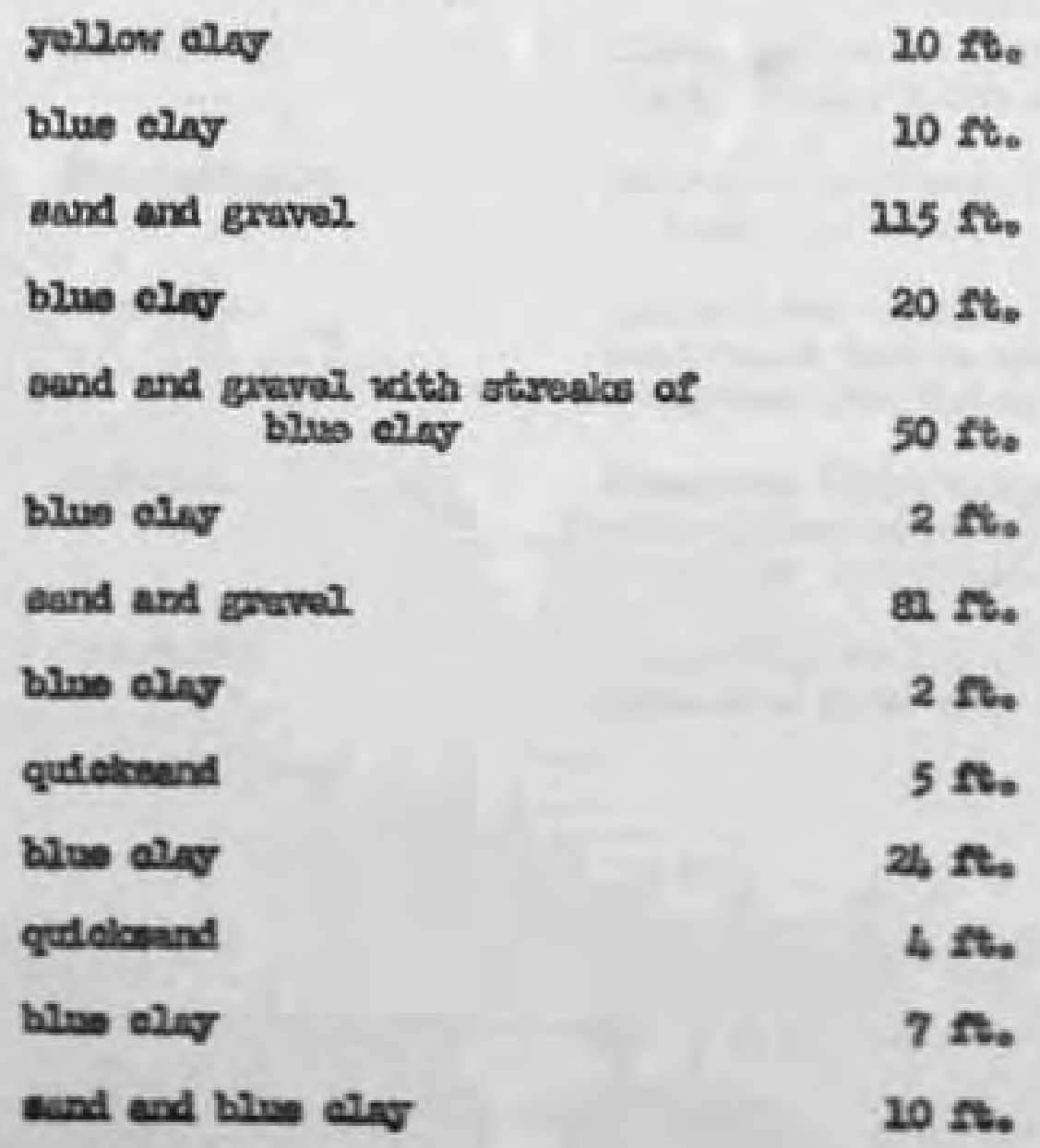


gravel

red boutlore alng

and

state

sand
$5 \mathrm{rt}$

$25 \mathrm{rt}$.

$5 \mathrm{ft}$.

$1 \mathrm{rt}$.

$9 \mathrm{rt}$.

Total depth

$375 \mathrm{rt}$.

Booling at Kondillwillo is afrilas to that at Molon woopt that the

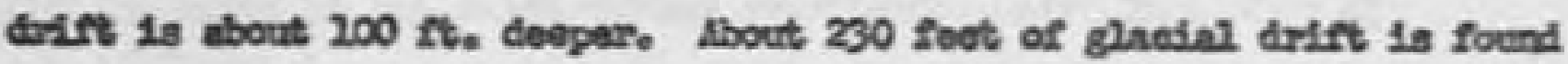
neas Lootto (II).

The bodroek formations of Noble County are ocrpoed of sadimantary rocka of Nleaiarippian ago in the northorn pert and of Dovousinn age in the oouthern part of the county. The follondng goologieal divistons arv rocognised in the rocorila of wils (11, po 452).

Qunternaxy

Mlosiondppian

Davondan

Bumeten

Ondovioen olaye, and ands (rooont)

clays, asude, gravole (Plolstooma)

shries, sandotonos (Bordion)

lismestone (Borden)

chales (llow Albary)

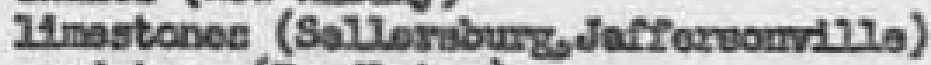

sandstone (Pandleton)

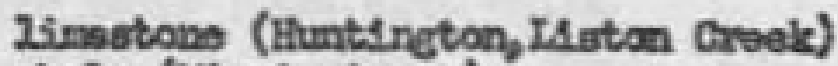
shale (OStostestinona)

2imestano (Rrassifiela)

Zimestane, shaloe (Rlohand-Bdden)

Zimestone (Ireution)ibhandisn 
ATPHOTO DITERPRETRIOU OF SOIL AREAS

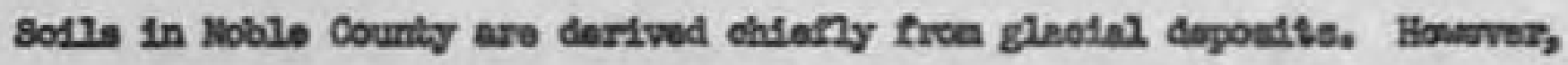
en approciabls anount of glaoinl-hurial and allurinl doposits aro reoogniesd, only a very listled extent of eolsen deposits are found vithin the counts.

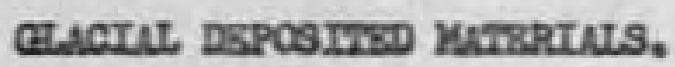

libble County is ooverod entirely by deop gleosil drith. The charataristios of the defft varies considiarably adth 2 and form of depositsion and tho vouroo of the glacior. The varlone deposits are diecussed so followst

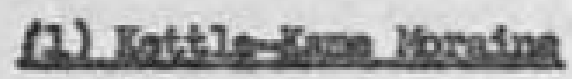

Tho loottlo-tans morainis areas occus in the vootem hale of the county. They are 2ifnted in extrant and ase often 1aolated or sopareted

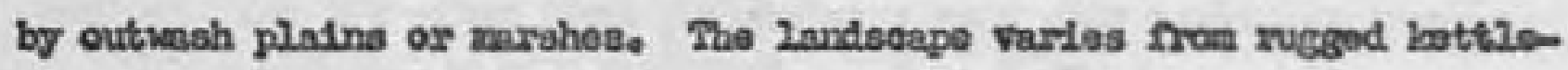
kane topography to modorately 1 rregulns hills and analos.

Parent mintortals in these aress are gonomuly oosrso-textured udth higher eley content on thoae meratines loostod noar the borter of Dollalb County. Pedologioully, the eotls of this rogtan beilong to tho Fox and Ylam Serles, prodondnately the Forr scondy loam, Kam phese. The aurfoce and subourfece sosts are shallow at the top of the knoll and are deopers tonard the foot of the knoll. Crose bodalng of sand and

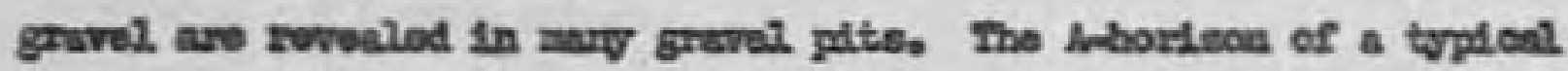
bas protsis sungod from waro to 15 inohas in depth, a revlondeh bronen sandy 10all The Bhorleon, fron 15 to 36 inehes in degth, contalins 2

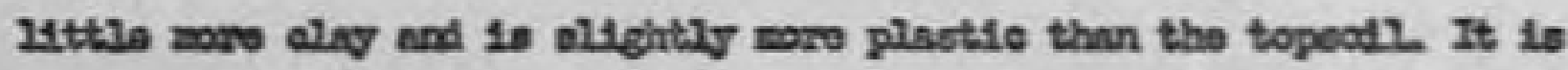




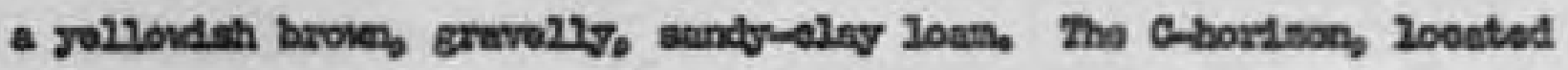
15 to 52 inohes from the surfeos, contaline no or vexy 21ttie elag. It

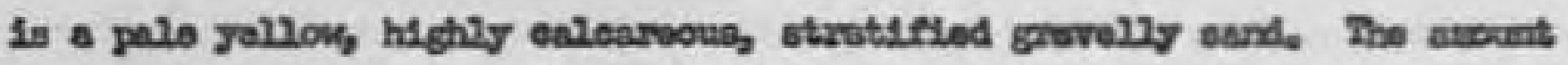
of graval varlas from one lroll to the other. Cobble atomes affit oocur arong the sand and gravel.

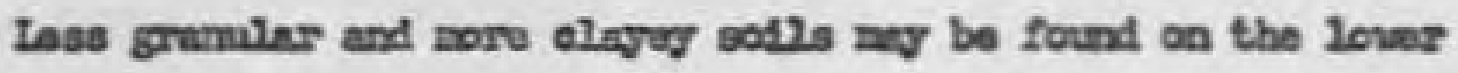

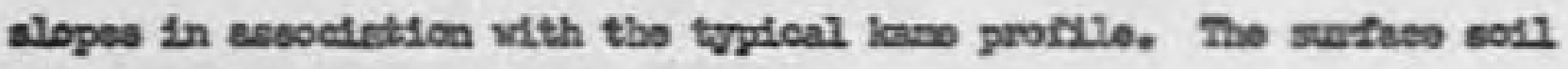
varlee troa a loen to a olaviloen, The subootl ranges from oley loen

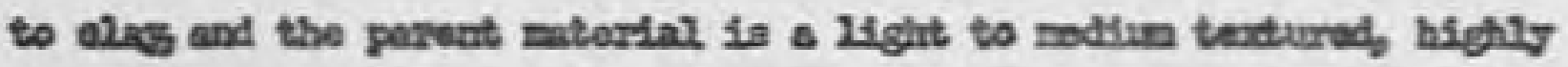
ealearocus drift.

In the ohallow depresestons or basing, hearg-testured solle of the

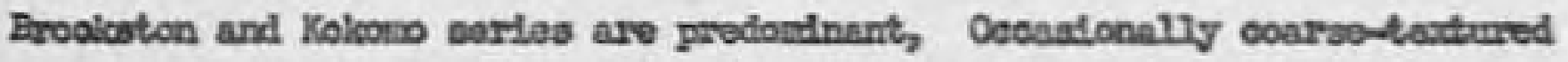

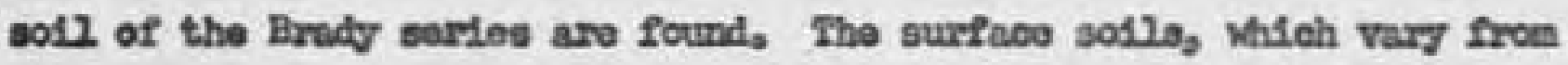

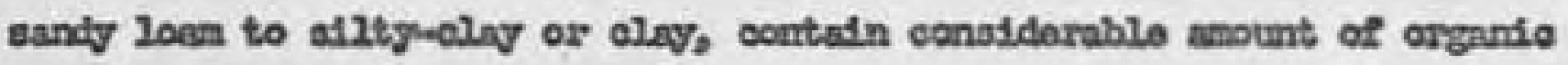
matter. The B-horlson norrally contains more aley perticloe than the surface layor. Tho parant matorials vary from otratsifled vand and

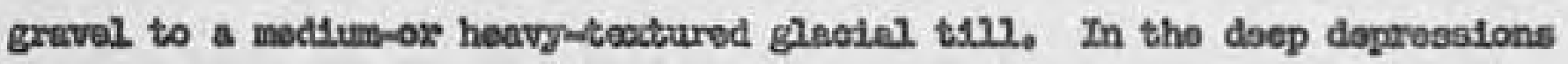
or bagins, aspoolally those surrounded by high lanalla, a collurial ail

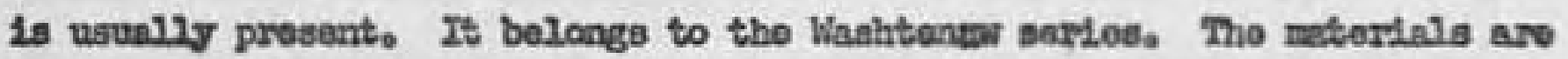

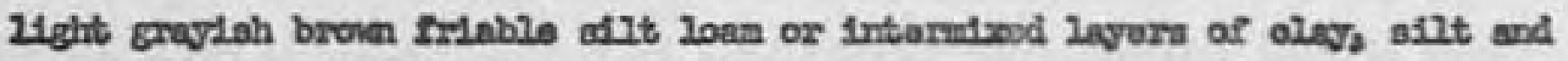
sand. The thiclonss of the colluriel deposit varies from 1 to 20 fert.

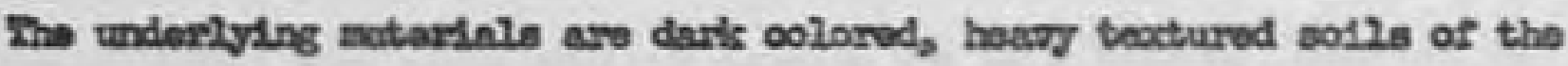

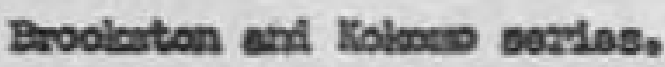

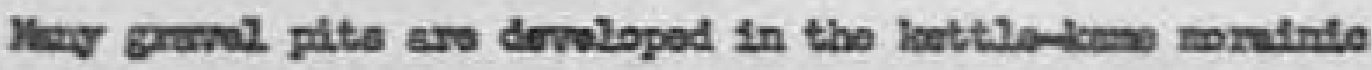
irpositseopoesally those in the western hale of the county. 


\section{(2) Radee Horetnes}

Addge moratine deposits occugy mare than hale of the aros of libblo County. Thay an be subdivided into diffarent texturil groupe, nacoly the

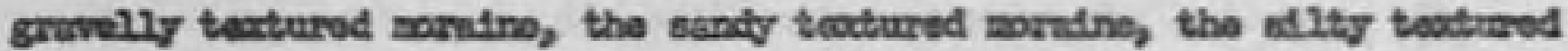
mording and the elayey trotured arrelne. Bnch group 19 difnousead in detad2 as follovat

\section{(a) Cravilly tarturod aldeg meraine}

Tho gravelly toutured ridge morafinas axe aleo acattored throughout

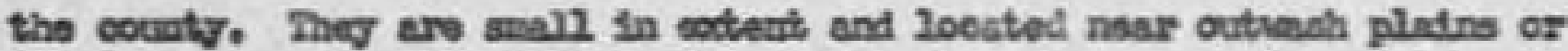

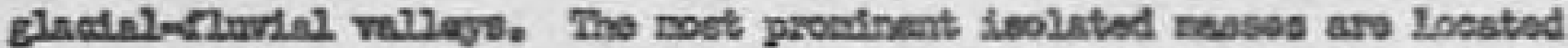
north of Kinnell, in the vicinity of Nubion, northoast of Kandallvilue and In the aoutheastem quarter of the oouty. Thoy renge fron low hllis and santos to a plttod sureces. The topograply is moh movo subdued than that of the lattlo-lome norasno.

Fngtnooring aolis of this group in genervi, are sandy to gravelly in teocturv. They bolong to the Fox and 15amt sorles pedologlosily. The

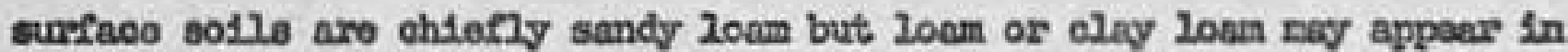
pleoes. The Buhorleon contratns a lfittle more olny than the layar above.

The paront matoriale vury from \& stratiflod and and graval (SW, SP, or

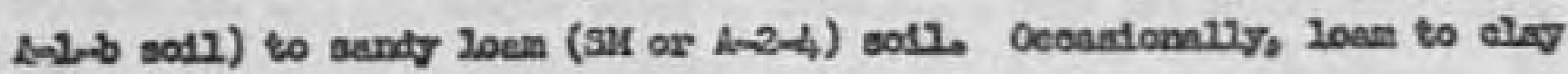

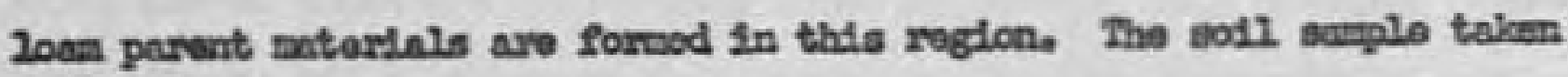
at alto $\mathrm{Hb}, 3$ is not a topteal prosslo for this roglon Howers it chore the poostble muintion and the grunular nature of this deposit. Ine teot deta (ese Tablo 2) Indioate that the 0011 is warg andy throughout

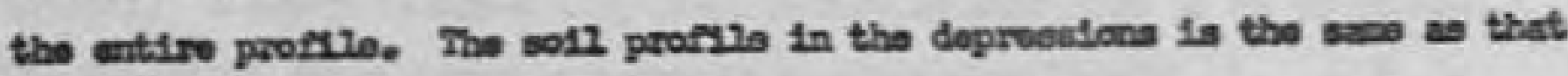

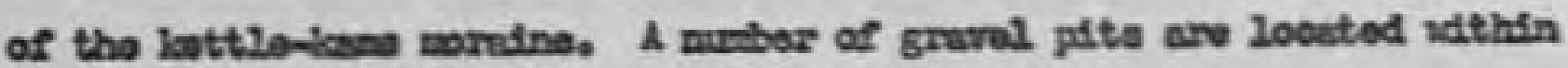
this deposit. Ibet of than lis on the oevtarn hale of the county. 


\section{(b) Santy Padae Norning}

A great portion of Iloblo County 10 oecupied to the sendy ridep morninis dopoeit. The main soctions of this mortine are loceted in the southnostern quarter, and the northecstom comer of the county. The oontimity of tho mes 1 dertroyed by a groat musber of outvenoh plefins and moik channals velioh out soross the morntno. The topography is

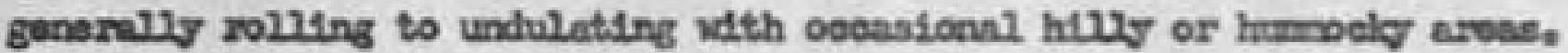
It oufibits a pitted elrphoto pettom on the sunds ridge morsine Located In tho morthnsitem part of the county as thone in Plgo, 6.

The najority of the soll in this ares belonor to the linud serlas. The surface teature varloe from $100 s e$ andy loan to frlabis loen or cley loen, The B-horleon varies from a grvvally or sendy alsy loan to clay. The pervent matarial is corposed of eanty loan, loss, silt loes, or alay loen idth sightly Ineroased asount of groval coutont. Soll sosples vera taken at alte Hos, 2, 4, and 9. Nathough nom of the earples on bo Clasaifiad as sand by the MSBO olaesifiention, they contafin approeiably

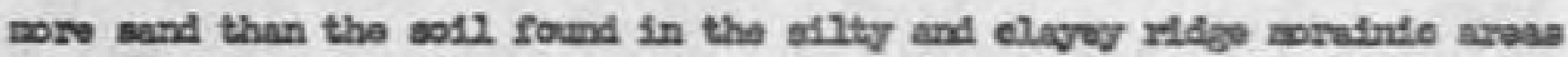
to be discuesed later.

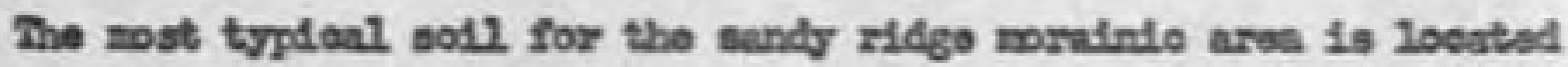

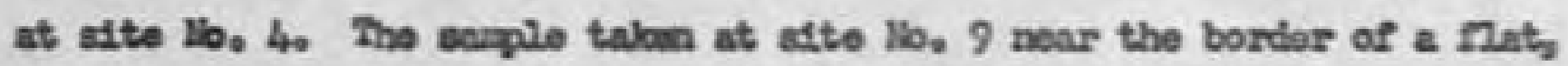

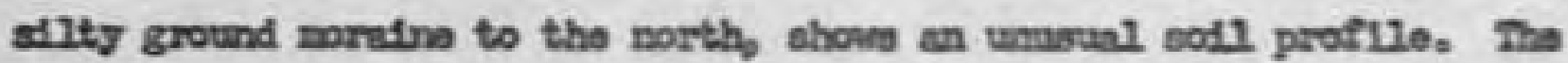
test alte is situated on the foot alope of a mound. The surface oull, about 9 inobes in depth, it a dark colored organte sunty loath the soll ahenged Into a light jollondah brone $200 s 0$ sandy loan irnodintely benoath the topeod1. A heavy toxturod eley loam is anoountered fron 36 to 50 inohes. The Chorteon takan dirvotly balow is a silty alay loam, 


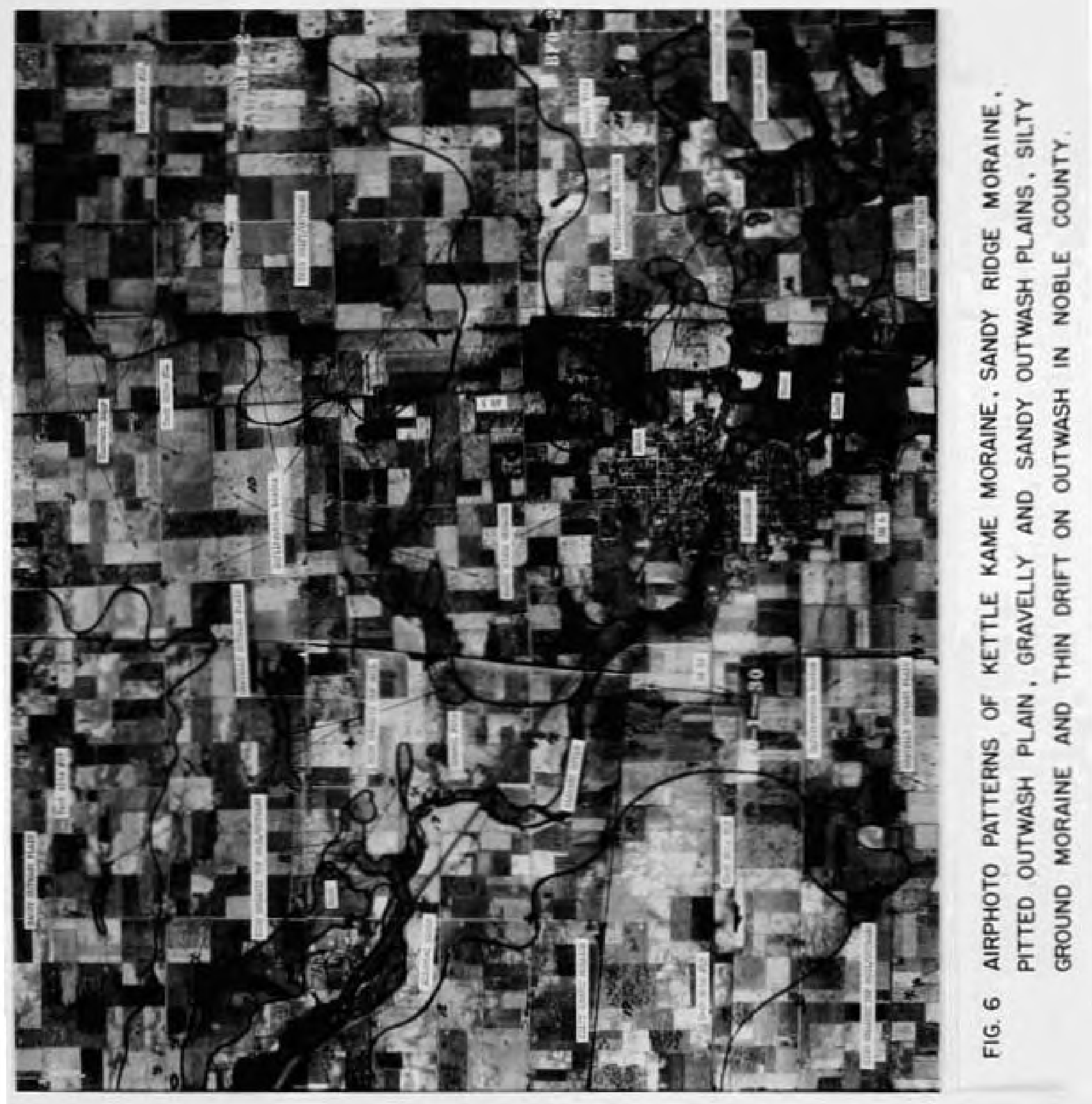


In the doproestons, eotles of Broolerton and Kolons sorilos axe prodorinant. The topsoll is a hidhily organde ality eley to elay. The subsoll has more olay content thap the abovo lagos and 10 genoraly olnsalfied

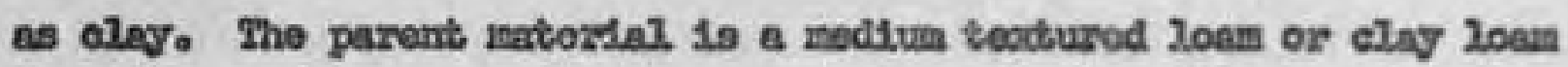
gleosal drift. In tho mare rugged areas, whore oxosion is pronounced,

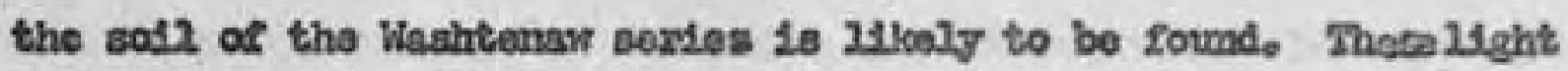
colared ealluvial nosile are depposted on top of the dark colored Brooketon os Kolones sadi.

Cravel pits are vexy fow and ere vidaly soatterod in this 2nd Soreno

\section{(a) Sutbr Page Morrains}

The stity xidge moret ne is confinod to the easters hale of loble

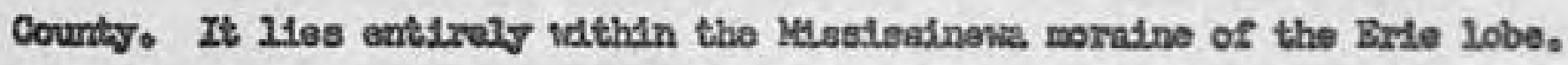
The topagraphy varles from hilly or rolleng to undulating. The suggod topography (vith looel reltaf up to 60 seat) is loated esst of Albion and in the vieinity of Creen Conter. Tha Inndscepe bocomes more gentite tonerd the south and oasto

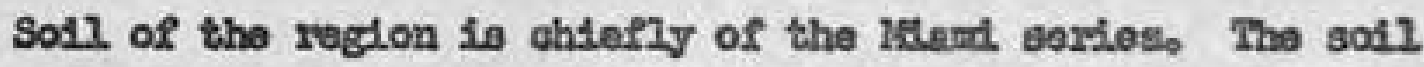
profilo consists of a 20am to olsy loam topsoli, a elay loam to clay subsoll and a loam to ailt loam parunt matosrial.

Solls of the Broaleston and Kokomo corlos are prodoutinant in the depressional areas. They are charsotariged by a silty olag to clay topeod b e elightigy more olsy content subsoll and a more coarse tendured parento materilal (20an to alas). 
(d) Crover Padare Yorating

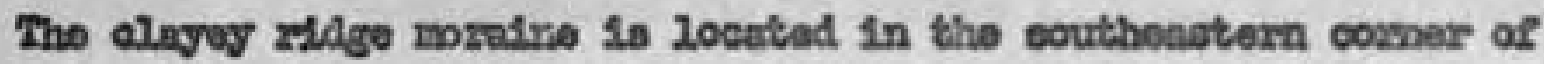
the eounity and costende about 70 square miles in axoe. It has a atrong hiluy

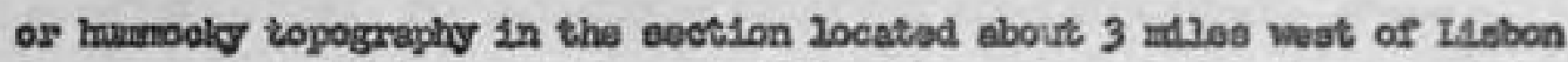
and also in a ganell aree about 2 milles northoost of Bge. The rest of tho ares is gontly salling to undulnting and becomes more aubluad tovard the eest。

The soll is this regiton is developod from a hoavy teotured gleosin. will whteh contains large quentitisa of dask gang sholo. It belonge to the

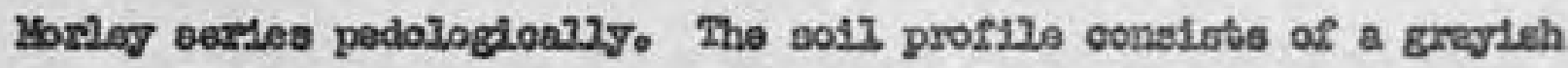
broven flrablo ailt loen topeo13, a ales subsoll and a highly onlecreous, olayeg parant matorial.

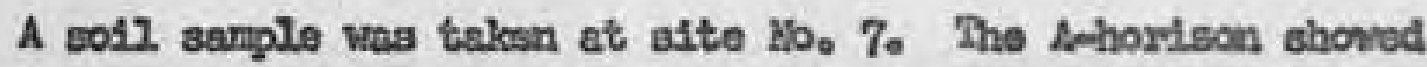
a thin (about 5 inohes in dopth), Iow orgente content, greylah brown heavy silzt 20an, The B-horison taken from 20 to 20 inches ves a hoavg olayey solit. The C-hoxizon ehored about the sems perventage of eley content but with considorably sore shale pebbles in the profile. The parent material wes sorevofat leas clavoy or plsotic than the layoz abovo and is classieled as olay actzo

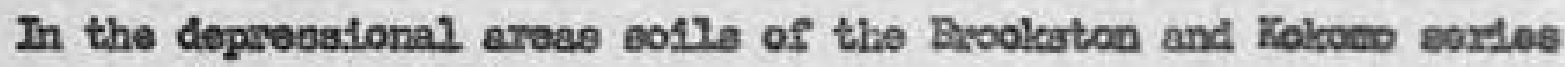

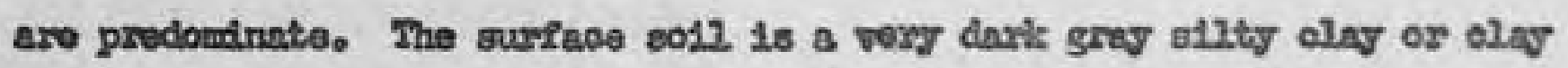
ralatively high in organis contrent, The Bunsiron is a mottled grav, yollow

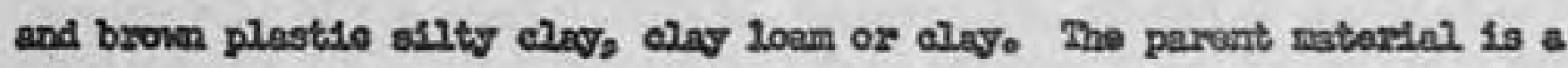

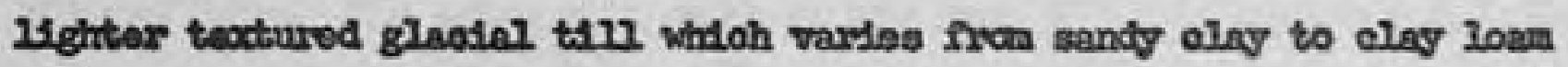
or oven olag. 
(3) Canonis loxating

A murber of ground maxinos aro recogritrod in thoble Oounty. Thoy

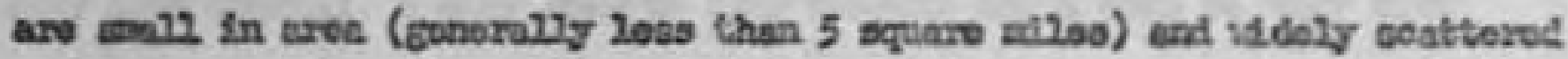

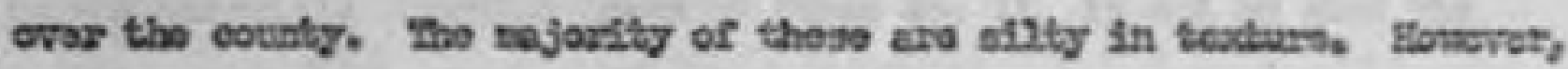
eanty and alsyoy tecturod groved muratnes aro found within the corrity.

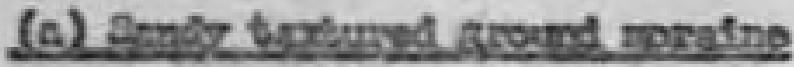

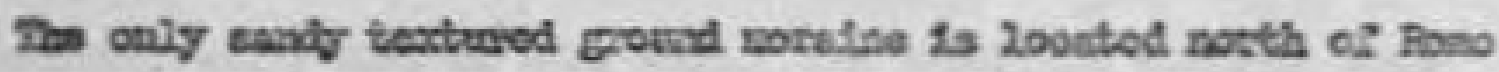
afily and eouth of libleottrilla. It is albut 2 square thas in oras. It exclosta a gently vatulating topograpiry.

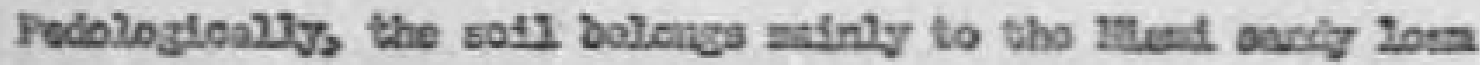

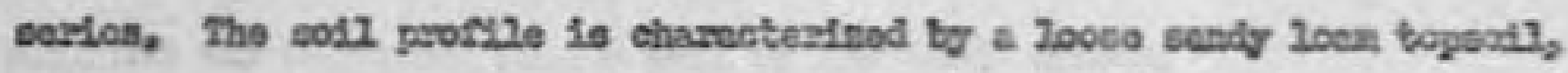

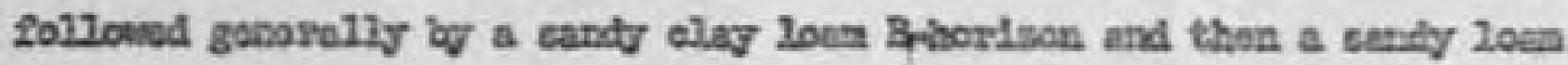
parome natorinl. Honwras, varistien nay be encouxterved in the D- and Q-horleons, In tho B-hordson a elcy to olay loas soll say bo fourd,

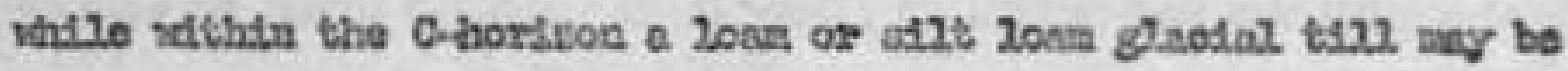
provent.

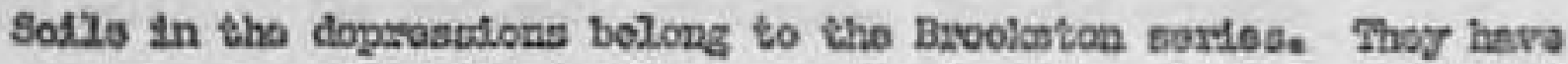

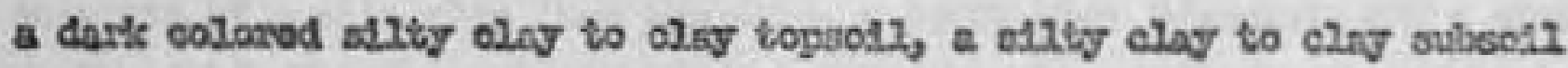

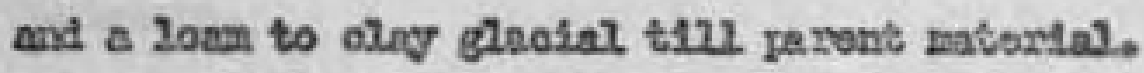

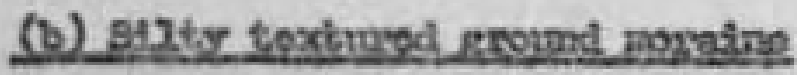

The silty testured grotend meratino are located morthy in the wastean hele of the county whore the depostis ave ralstod to the Bugher glootnl lobe. Tho topogrupity varles trou noar lovel to gantly triduleting.

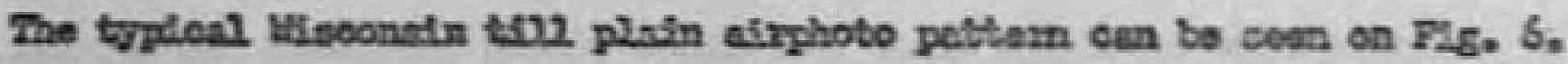




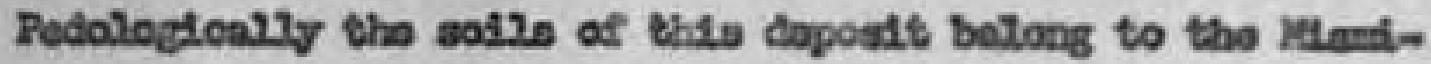

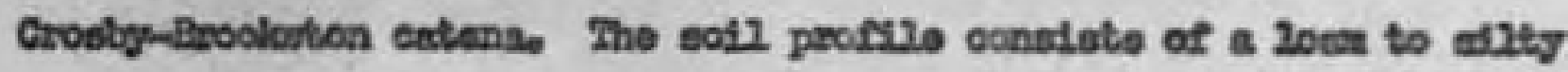

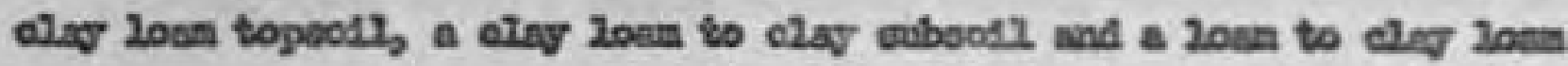

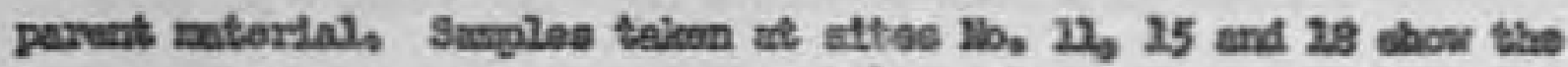
variation of the solles in this reglon.

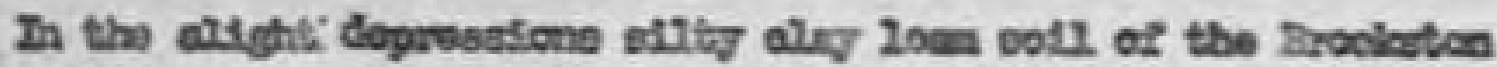

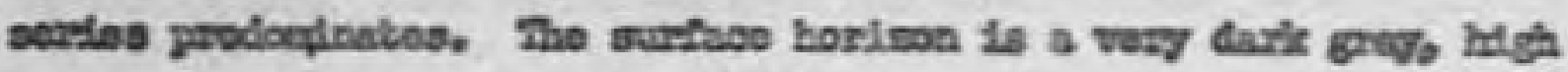

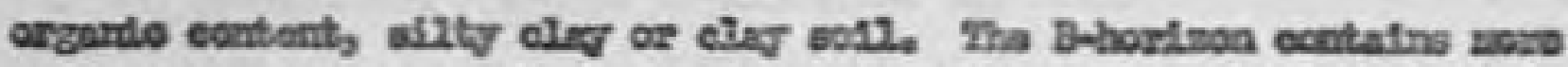

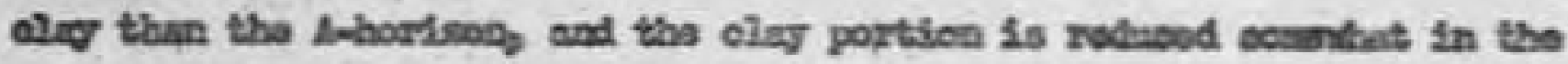

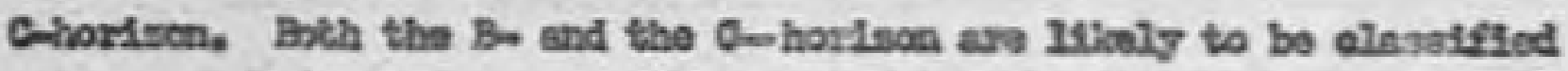

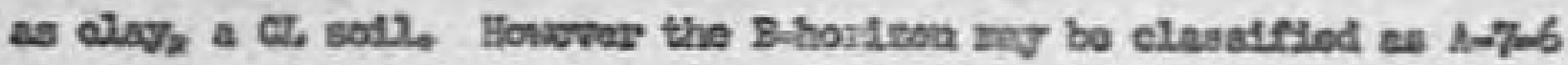

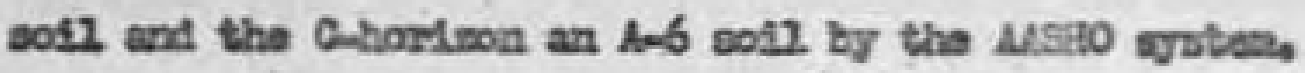

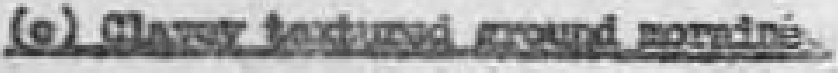

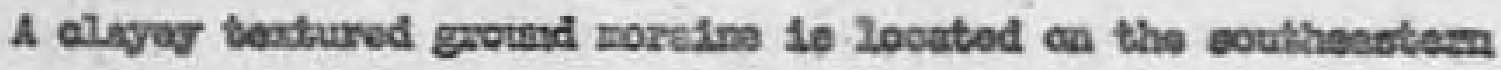

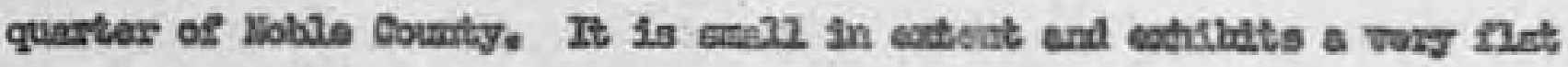

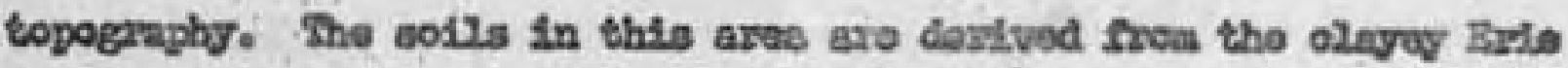

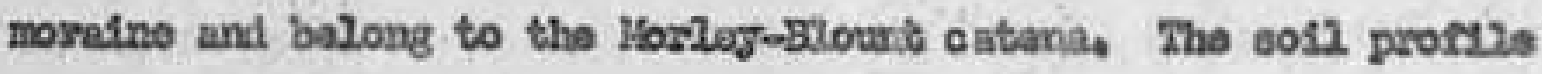

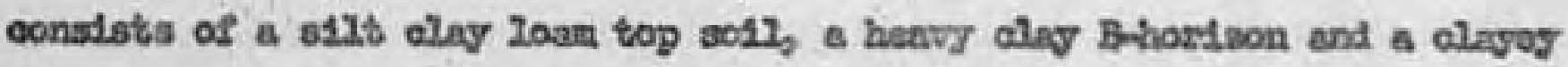
Ghorison.

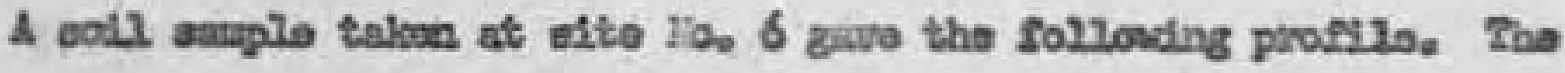

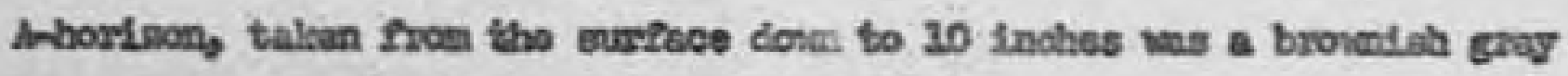

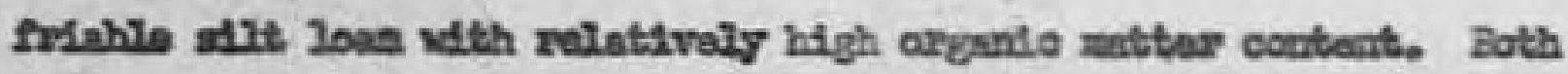
and and aflt contents cooreesed in the B-horleon vatle the eles occitads

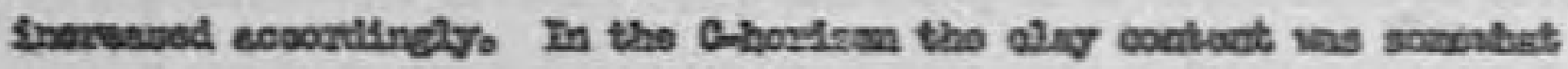

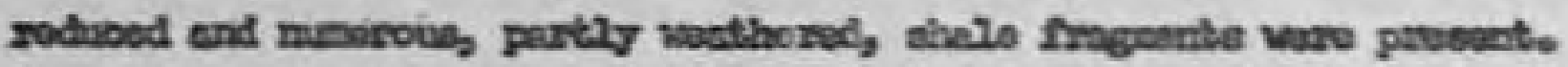
Tho parwat zatoriel is elasesefied as a oley solp. 


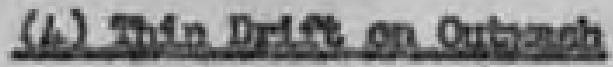

An arva, about 6 squere millos in coctent, zocated northoest of IAgoniar is a ragion that has a flat to unitulating oveawli topography.

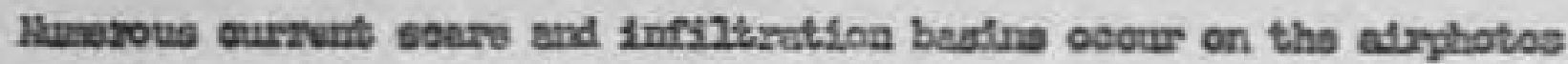

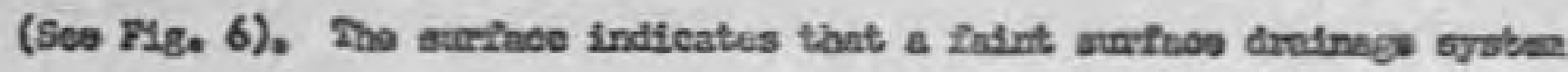

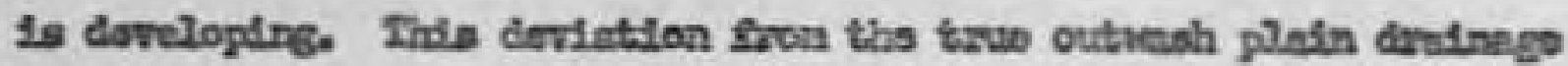

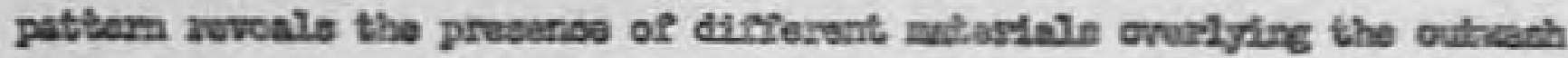
ploin,

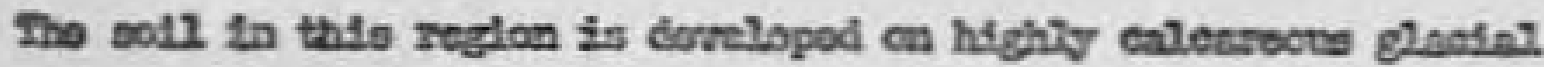

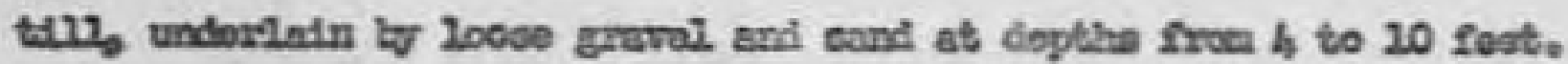
Tho uppos part of the proftio is essentianly the soms as Miend loea and tho proste bolonge to tho Venelce pealos.

The ooll proryle convists of a loan to elay loem topoots, a

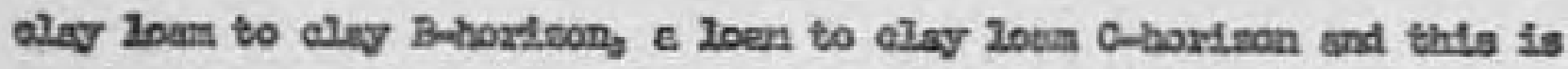
underialn by atratselad grovel and aend.

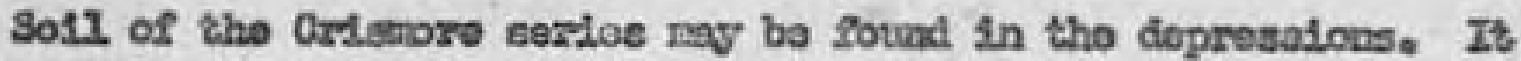

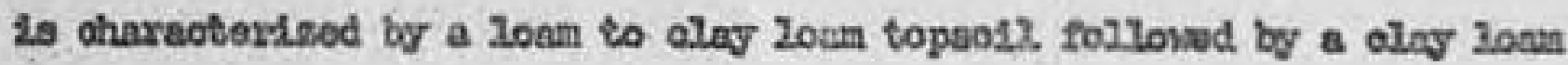

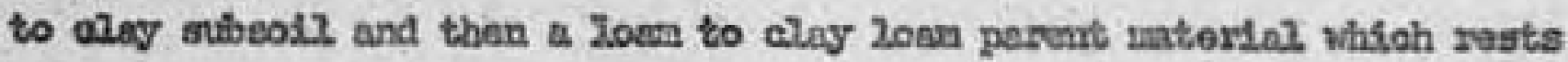

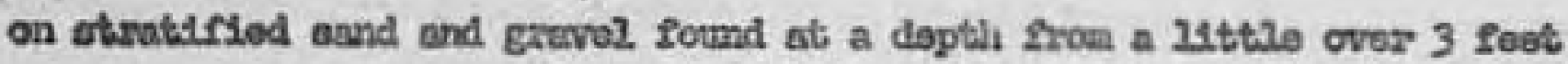
to about 20 seet.

\section{(5). Eetrone and Isres}

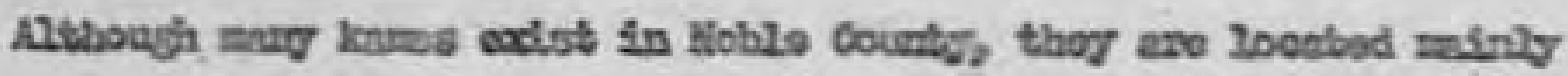

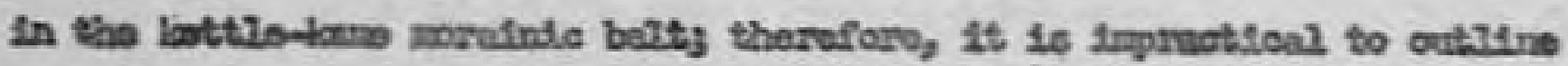

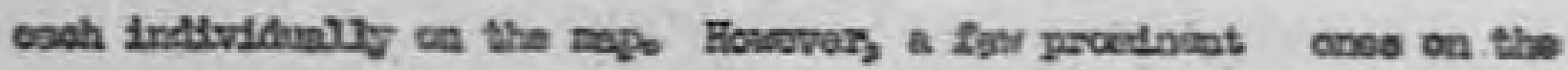

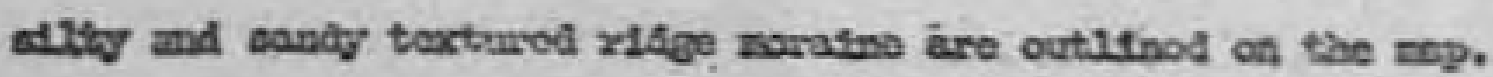

Thare are a nubere of ahort, orall eskows in the county. Ingy 


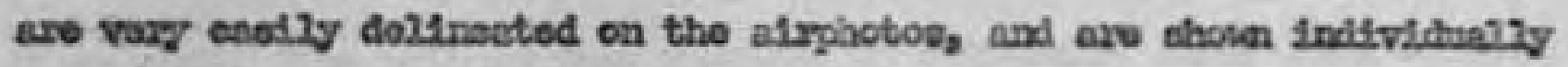

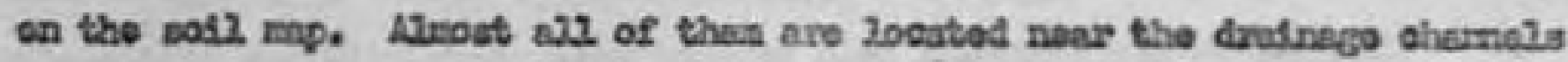
idthin the southotin hale of the oounty. Thare is cha, honvwer, neasily ord ablo Iong, 2oonted near Berrellent in the rosthorn hole of tho county. The solle doveloped an these forkatsons aro genozelly of the Fox soriles. Tho typtoel prorsle is about the was as that of the bottlelave mraline.

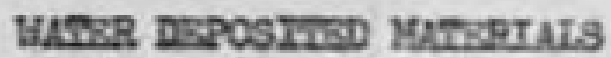

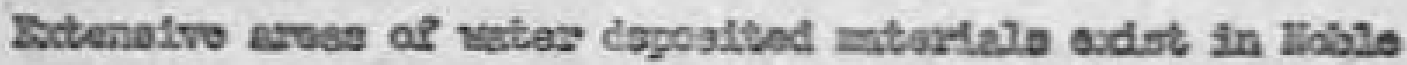

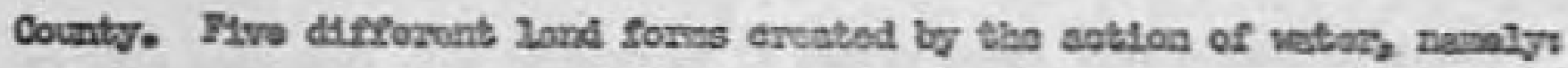

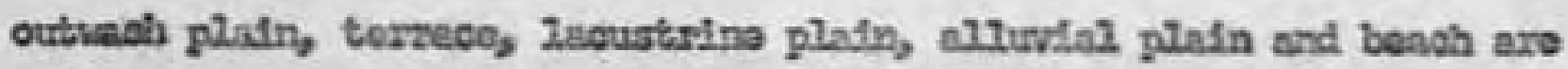
dieouneed as followet

\section{(1) Outionsh Rloting}

Neasisy hale of the morthestedn seotiloa of Noblo County is occugdod by outwash plain copostits. Othors aro locsted nota Burg Oals and east of

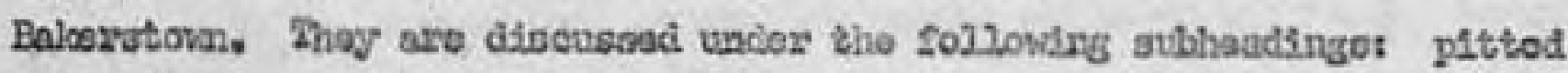

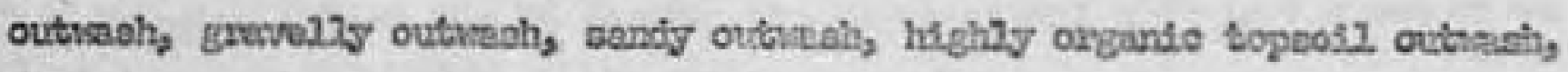
then outhneh on drise sad thin outialh on zolnobod.

\section{(e) gxibed outosin ninin}

The woet procineht psttad outheoh platns avo locutad north of

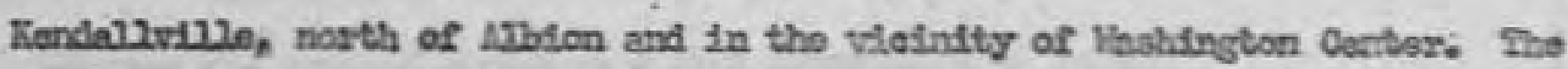

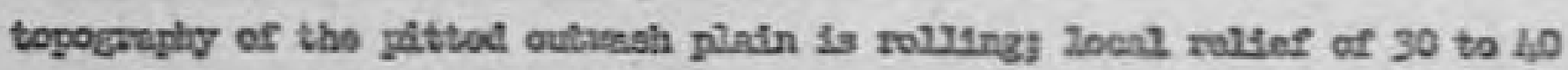
Poot in ragnitude is rot unoocano.

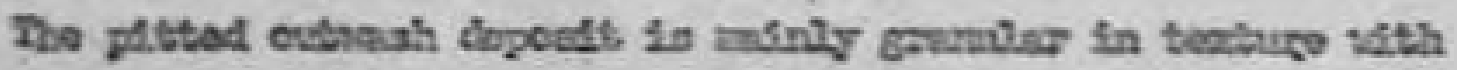

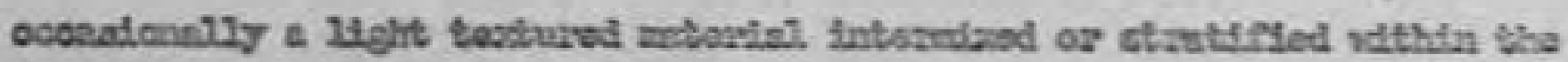


propste. The mafor sols of the aree bolonge to the Fox soxlas idth aore

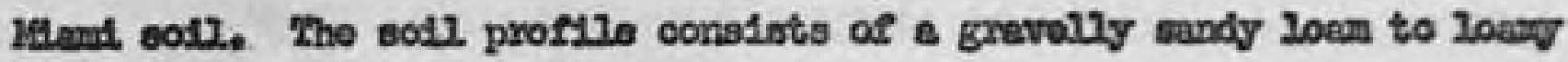

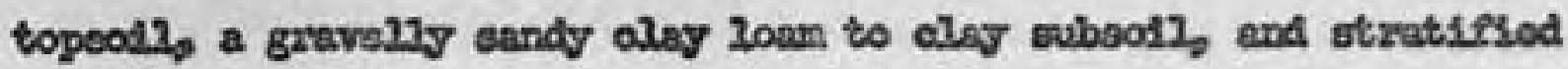
garvel and eand or a loam perrent material.

In the dopressions, the soil groft 20 is about the game as that of the

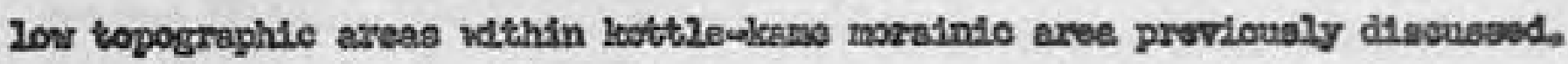
Wumerous man-mede grovel pite axe located on those plited outhash platno.

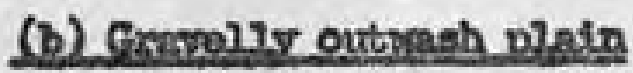

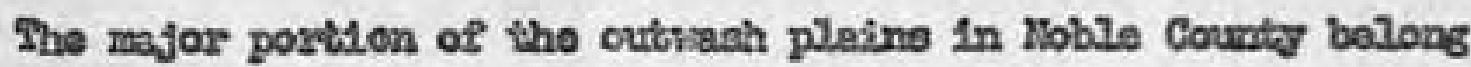
to this catogory. The topography 10 noariy $20 v a l$ nith couritiosa mubers

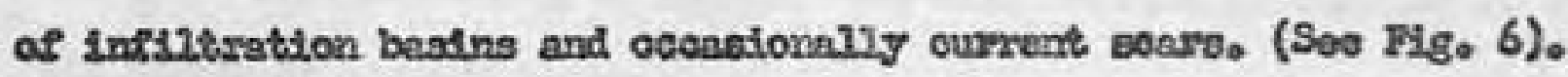

Soll of the grevelly outhosh plesin in Noble County belongs to

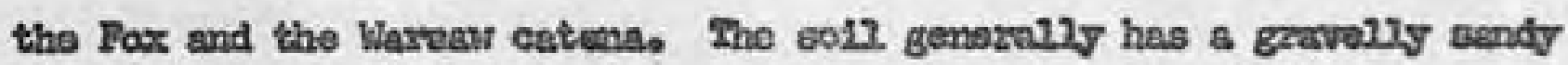

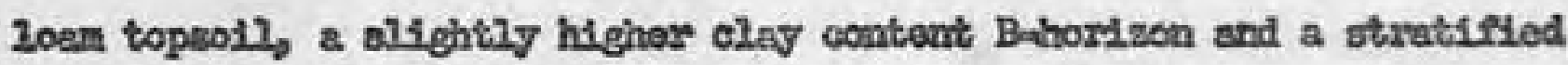
sand and gravel, G-hossoron.

In the depsesetions or ahavion boolns solils of the Brady, Wertland

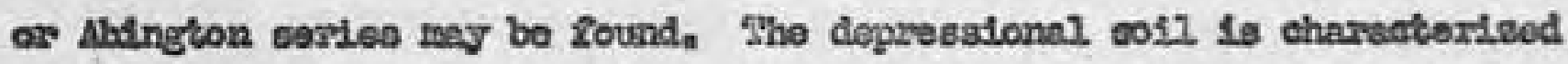
by having a daris colored, highly organif sandy loan to alayog loam topaotil.

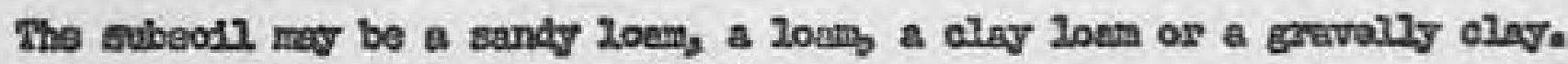
This is underiatin to a stratsisted graval and and parent metorial.

Gaval pits axo not doveloped too extensively in this rogion becenses the depoaft contasins a bigh paroectage of sand. 


\section{(c) Sangtr cutageh nising}

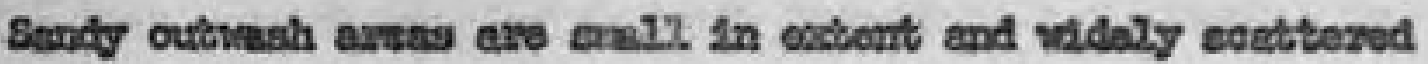
velthin Mobio Courstry. The lasgor aseas exv loouted in the nopthueatom comnes of the county and east of Cuspervizle. Tho arees are Rlat and

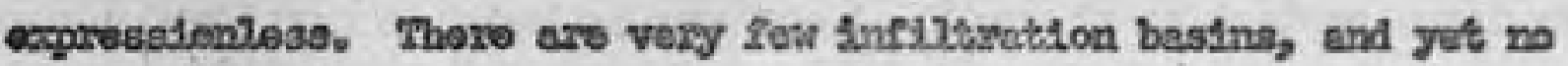
suresace drainage doveloproont is formd on the eandy outreah plains. Pedological solits in thls regton are chloriy of the Por, Houns

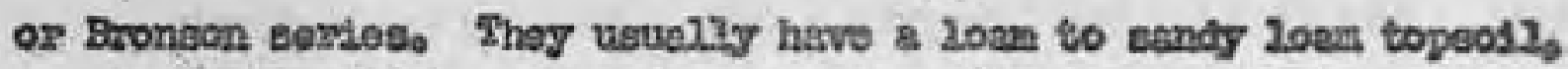

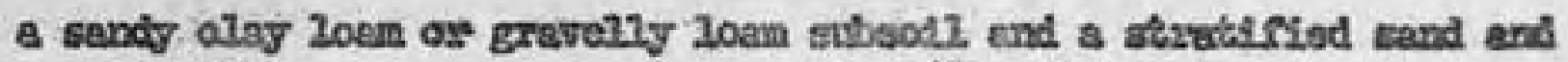

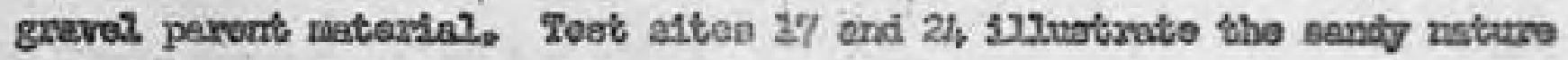
of these depoarte.

Th deproesions or besins, the soil profile is alustare to that of the gavialy outioseh platro

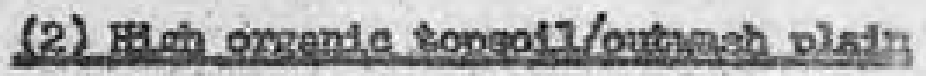

Only a set nerrow strips are oosuphed by the high organle

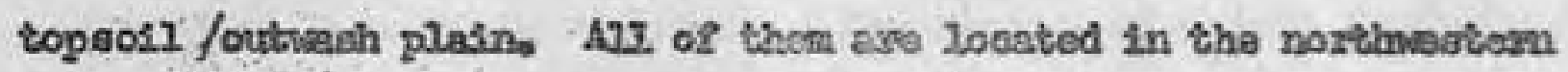
eection of the oountey. This deporit is cieveloped on the deprossional nats. The curfage is very enpoth encl ranotonous. These arves all have a unisora dayts gaty photo tom and are enatiy dolinoatod on the aozins photograpina.

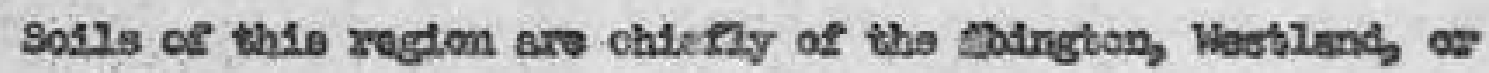

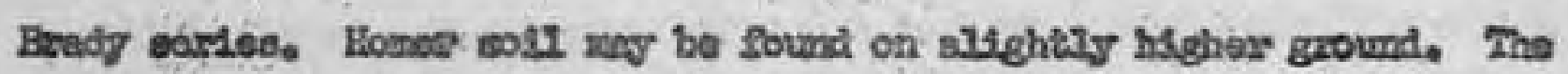

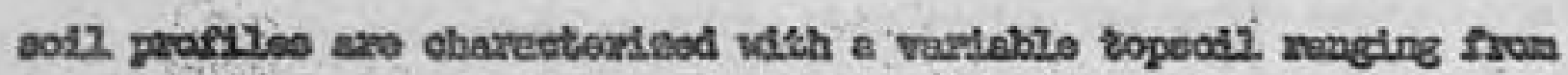
oley to samdy Jaan with Mgh ergans.e content within the upper 20 inohes. The Bhorrison also vexioe from a sondy or grovolly atay $20 a n$ to alsy with

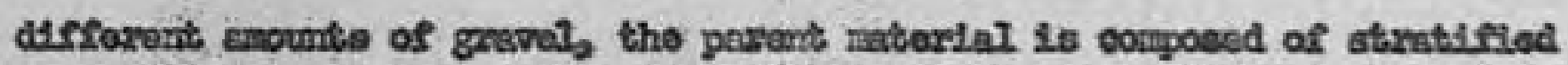
ands and grevelis. 


\section{(3) Thin ontrash on oxpess}

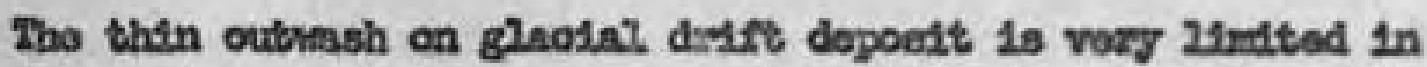
Noble Countay. If oocurs in the viointty of Fondallvily and is less then one square ifle in arva. Although thd ares has an overall platn turface,

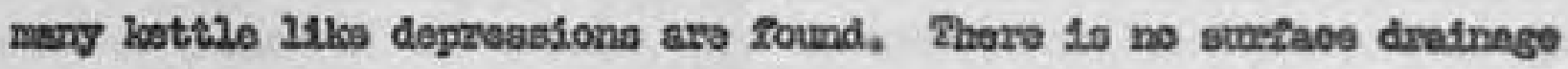
devalogment on this deporsit.

Sosi of this rogion is desienated as Fondainvilue by the pedologist.

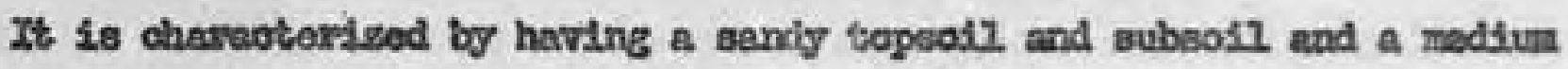
teatured glastal till balow.

\section{(4) Thin oxthwash on ialgebed}

Thoso are tho separato areas in Noble County having a thin outhash deposit ovorisjing a alegrey lakobed. The lazger one, a 3ittle oves 2 square miles in alse, is loostod about 2i mileo east of Alblon. The smallar ons,

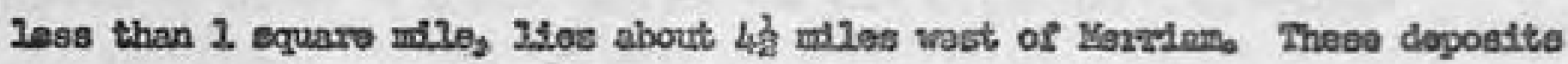

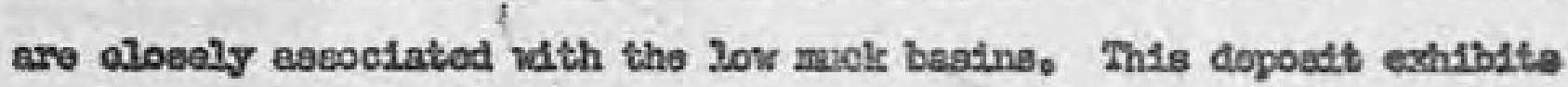

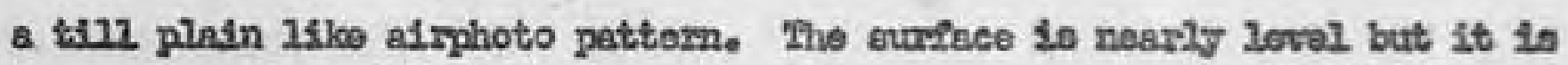
disturbed by gome fraint inflitiration mavics and ecattered suriace dralnago ganlese.

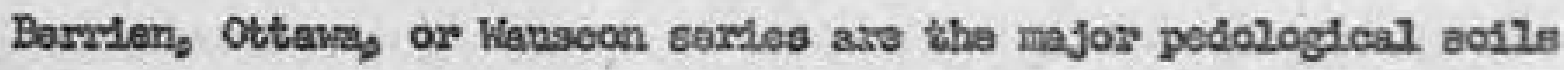
of this deposit. The soil prosilo consists of a sandy or sendy loem topeo17, a Istitle heavier subeoll overilying a jectotitine olsy with thin Ienses of eend and allt at a depth varying from 2 feot to 6 fort belon the surface.

In the copprosatone vdthin this segton the cendy outwash ang be

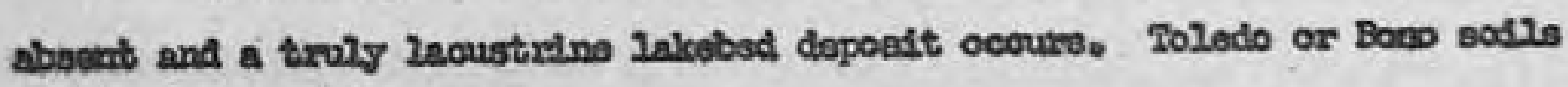
mog bo found. The prostio is a clagey rosl throughout. 
(5) Terreese

Terraces are gonorally found along major drainago ohnnnol. In

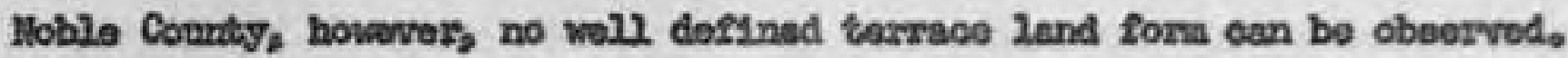
The anily on that may be consicered as torrace is locnted on the southeastern cornes of the coumby. The chnracteriotis broak botiven upiand and terrece 18 not presont. Sous infiztration bastns and current mexks oceur on the afrphoto patiom of this area.

The terraces are composed of atratiflod sands and grevols.

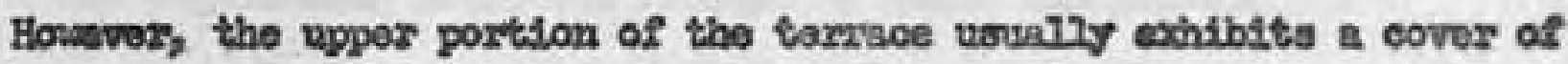

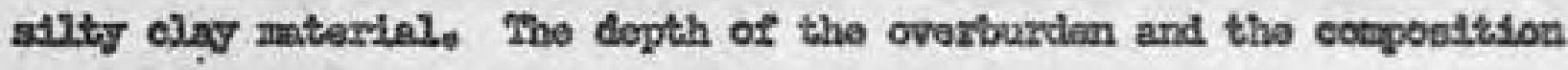
of the doposit vaxies greatig from place to placo.

The mejor pedologioel botl af the tozrace is ganorally of the Fox sozjles. The surfaco aot varles from sandy loam to loang the Bhositron is gonorally a eand 2oam and the pasent matorial a stratifled grevoly aand.

\section{(6) Lagustarine nlain}

Thase are a few lacuetinine deposits in Noblo County. The Iargest ono, about 2 square milea in area 1 s loceted about 4 millea wast of

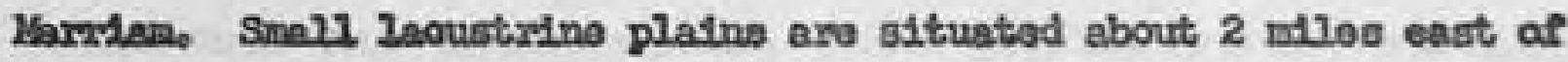
Nubion and at the southoastorn corner of the county. The lacustrine plains are genazally noariy lovel, and are only alightly higher than thois edjeoun muok besting.

A undform gray tome is roglstared on the adrphotos and no sunetaes dratnage development is shoun in this arve

Falton and Foledo axe the mefor pedologioal aodls in this area. The sosil profls is chaxnotorided by having a silit loam to alay topoofl

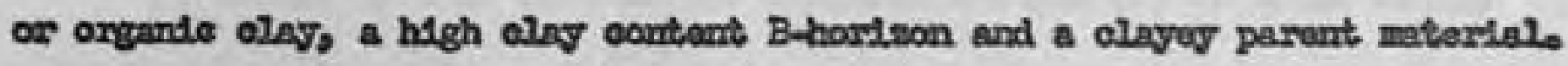


In the shallow doproastoris Bono so12 is prodorthant. The eo13

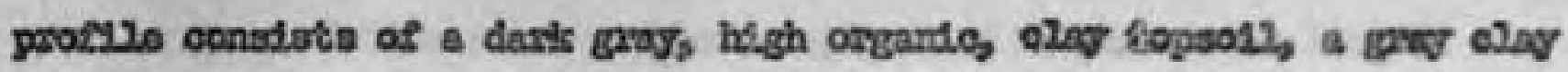

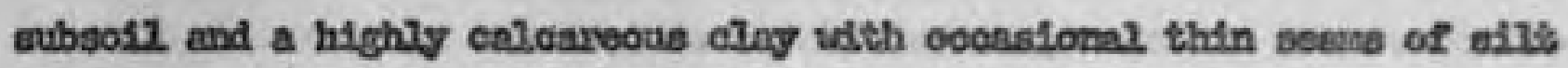
or vorg 2 in and perout naterias.

\section{(7). A33xider Pzoin}

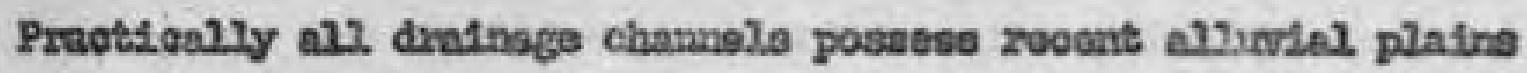
(Elood pinina) s hoverox, onity those of oongiderable gisa are shonan on the enginearing 6osls map because of scalo 2indtakion,

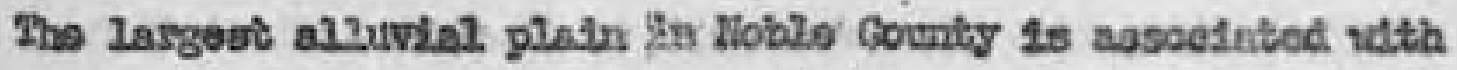

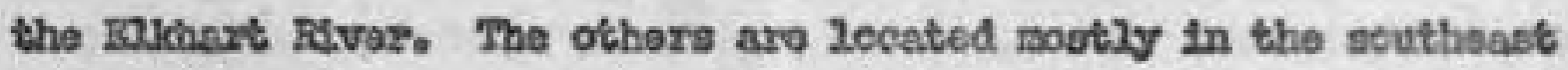
quaxter of the aotmty. Nost of the elluvilal platha are elat.

The teature of the aliuvial ceposite varies gaveshly from ane pleas to the othar dopending manly on tha nature of the clrasnage beatn. Those that are located in the norkinesteren section of the oounty aro coaree in tsactura, Griffin aodi is protoninant in this section. It

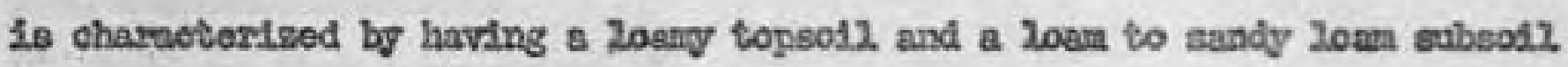
that gxados into strattelied sand, silt, elay and gravel at varlous dopth. Tho teacture of the allwviel plaing in the other sections is Siner than those aforementionod, Since thog are dorived sron silty or

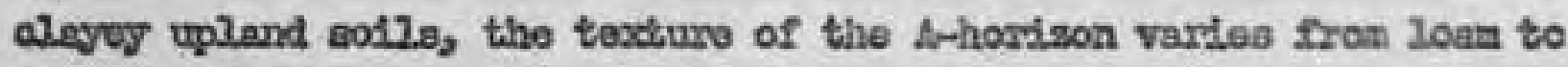

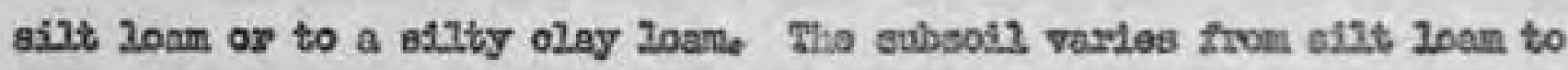
Ioan with ocoarional thin Ieyoze of fine sand. Send and gravol nay be sound at a dapth of about 40 Inches from the surface. Podologleally this eolil belongs to the Bal sersies.

\section{(8) Sond Beach}

South of Wale talco in the Eouthwostern quartor of Woblo County thexe are ason bosch dopoesta, Thls zand occuples areas boriering leked 


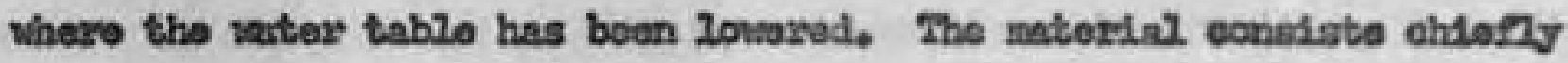
of a indxture of IIne sand and coarae gravel wath ocosalonnl laxge rounded ctones. The material is stiratiesed in plsoes and 1te composition varies.

\section{WITD DFPOSTMED WARYERTAT}

Theze are a few Lindred eotsim aand depootits within tho oounty.

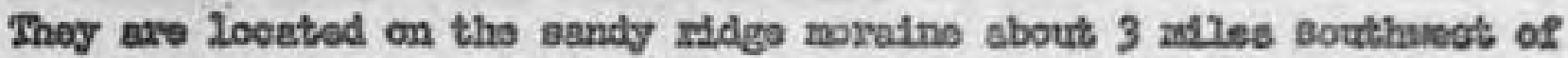

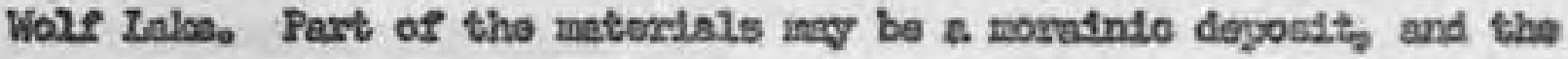
top pent is destinitaly a duposit of the subeequent wind eotion. The

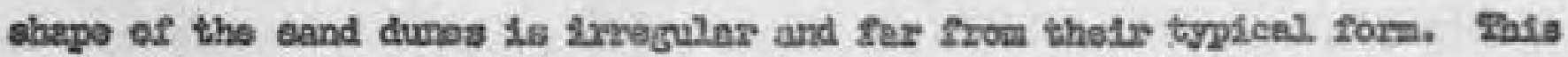

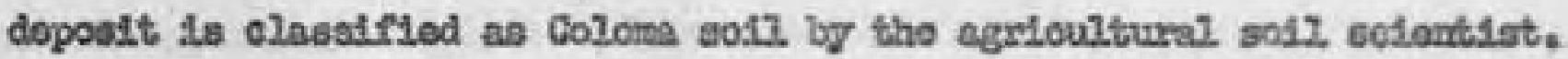

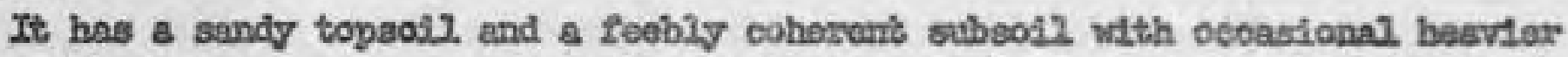

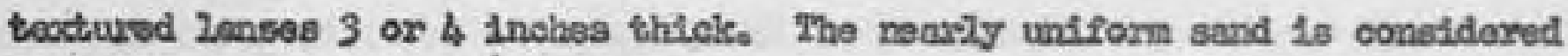
as a poorisy greded sando

\section{IDSGEITAMEOUS DORYATIONS}

\section{(3) Beat and zanck Dapresselong}

The chiof orgende sobl of Noble County is mek that ocoure in manrous lettile dopressions. Peets aro found underifying the deomposed muak in mung places vhere oxdidation is vary slow or inoffeotive.

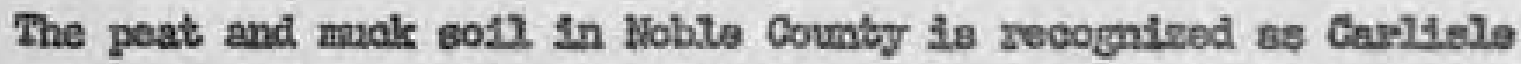
mak, Edruxds mek, Houghton menck and Kerston mek by the agronondst, Noot of the peats are desived from Sphaguva zosses. For quantsty and qualtity of peat, Mbble Courcty zanks as one of the forenost countates of tho state (12). The peat deposits vary in size and depth. The large ones mey be us to 500 acros in arec, end the orgando matersel may be as thiok as

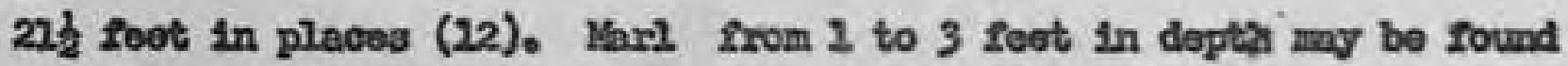


undorsying the peat and maok doposits in some aveas. If is a sort eexthy

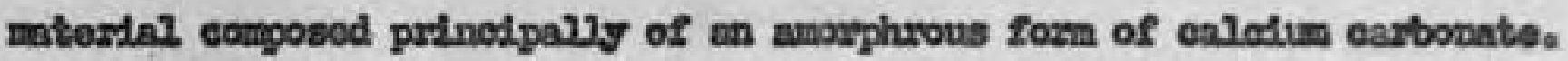
SAnco it is aleo undestrabla from the englnoersing atendpolint, no separation 18 mede from the peat and whok in the genoral eot2 proftlo.

Since the stse and dopth of theoe dopostte varles greatiy from ane deposit to the othors, Stold Imvortigation $20 x$ each Individual doposit Is nocesany before final dosign la nade.

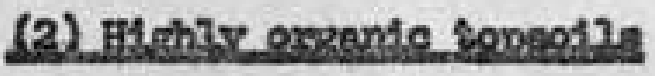

Depsessed arees, where intorrael drosnage is somonhat rotarded by the high ground water tablo, give sise to the accumilation of considervblo amounts of organic topaot?. There are a muber of swoh axvas in lloblo County. Soms of them are 20ested next to the anok pockets. The parent matorlal underiying the organic topsoil is essentinlily the srmo as those of the swrrounding minoral soil ereas. Where large arens exdity an

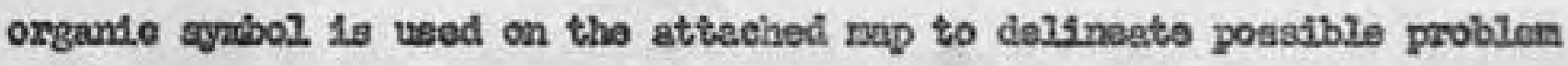
ootz axeas. 


\section{BORLTOGZAPHY}

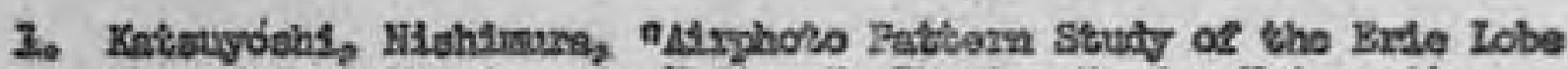

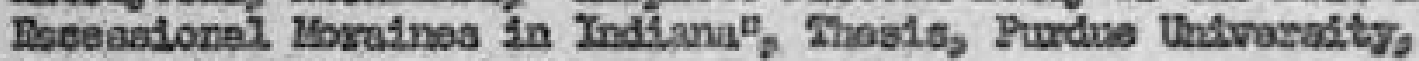
Iefayotte, Inaliane, 2952,

2. Prosti, R, Es ot ef Hanval on the Mrphoto Iritexpretation of Solls

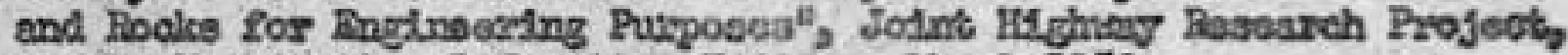
Rurdue thiveradty, Lasaveties, Inciliana, Warch 1953.

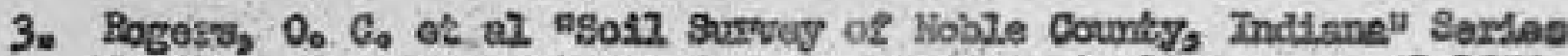
1940 no. 3, Undzed States Depentomiti os Agricuilturs. Apusz 2953.

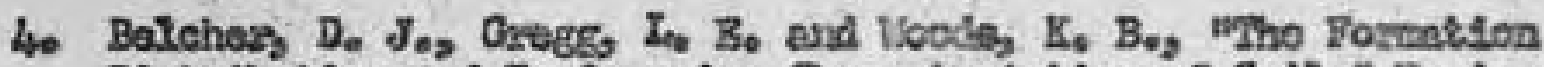

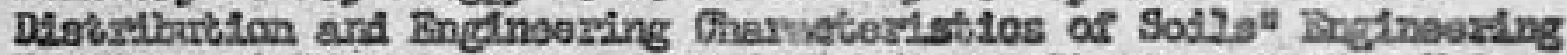

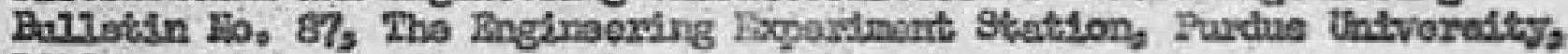
2943.

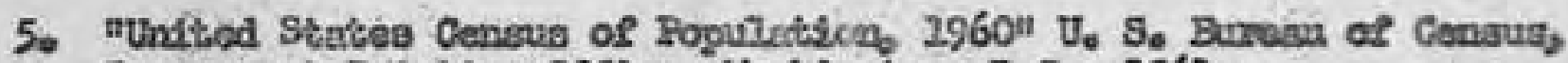

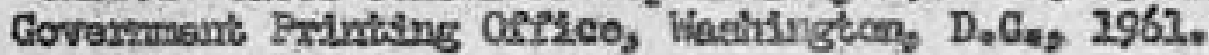

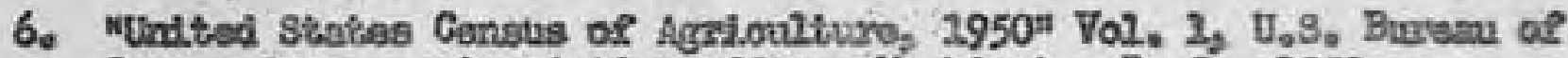

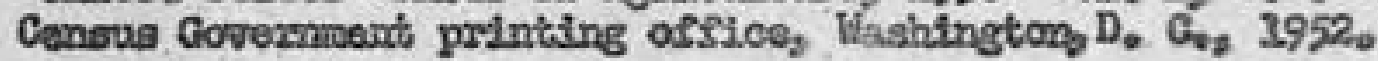

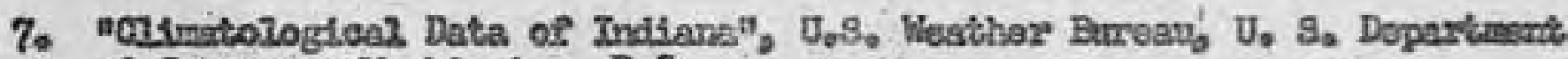
of Coinerevo, Weshington, $\mathrm{D}_{0} \mathrm{C}_{0}$

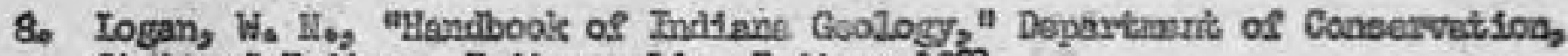
Strete of Indians, Indsanapolis, Irdiena 2,62.

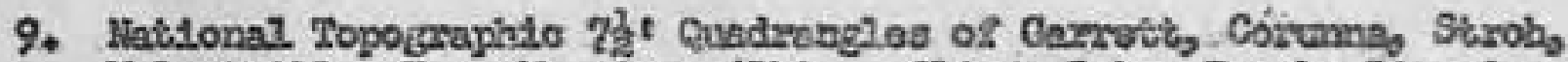

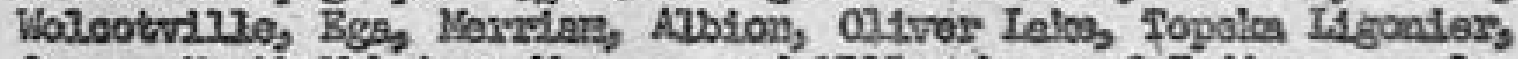

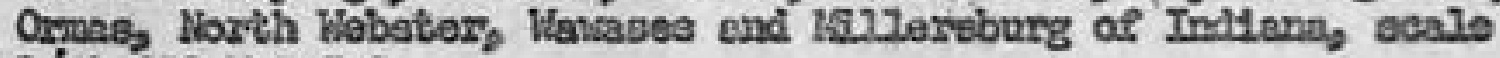

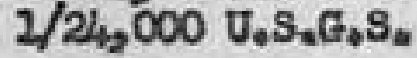

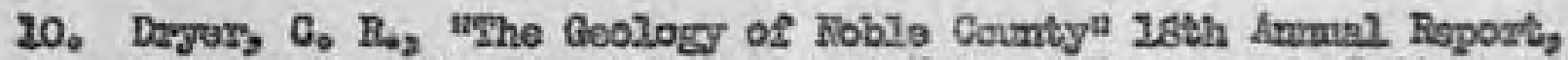

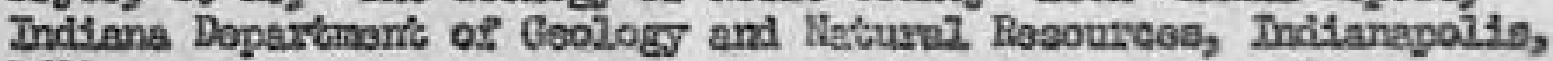
$18 \%$

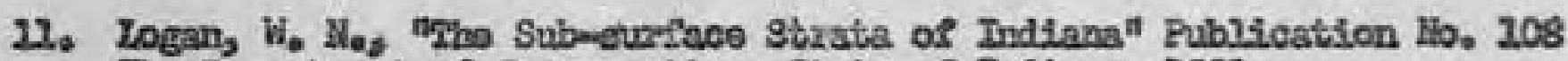

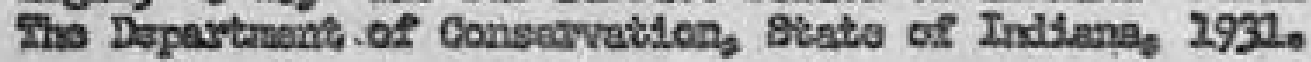

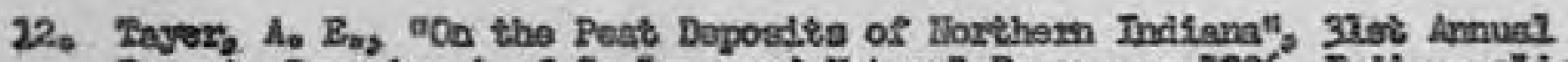

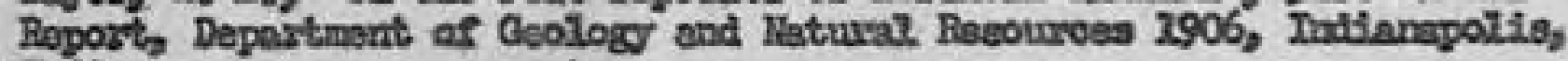
Indiane. 


\begin{tabular}{|c|c|c|c|c|c|c|c|c|c|c|c|c|c|c|c|c|}
\hline 2 & $=$ & $\frac{k}{n}$ & 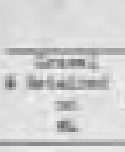 & 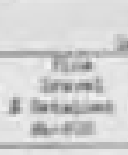 & 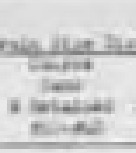 & $\lim _{x \rightarrow 0}$ & $\begin{array}{l}4=8 \\
y=1\end{array}$ & 278 & $\frac{4+6}{5}$ & $\frac{n+m e}{6}$ & $\frac{\text { at }}{\frac{14}{x}}$ & Aifies & inte & 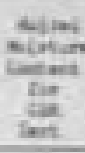 & mank- & 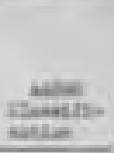 \\
\hline \multirow[t]{3}{*}{$x$} & + & $7-36$ & 1 & $*$ & , & is & - & 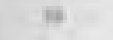 & $x$ & 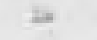 & It,y & $m$ & , & 20 & $a$ & 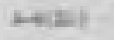 \\
\hline & $*$ & 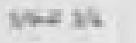 & $=$ & 2 & 3 & $a$ & if & is & A & $a$ & ans & ans & 4 & 20.7 & $a$ & motat \\
\hline & r & dake & $z$ & $i$ & 1 & b & $\alpha$ & $u$ & - & a & min & was. & 4 & $z a$ & is & whin \\
\hline \multirow[t]{2}{*}{4} & $*$ & What & I & $x$ & $*$ & 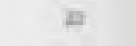 & $=$ & \& & 4 & $*$ & IF) & ins & w & at. & $=$ & W. \\
\hline & 4 & . 4 - & 3 & 4 & * & $2 x$ & 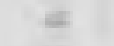 & w & $a$ & $x$ & ats & ate & 4 & Lit & $=$ & $-\infty$ \\
\hline \multirow[t]{3}{*}{ 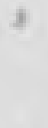 } & + & $57-2$ & 3 & - & a & 2 & at & $u$ & a & - & $\mathrm{si}+$ & $\tan x$ & $x$ & at & 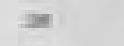 & telas \\
\hline & 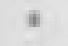 & 120.92 & $*$ & 4 & w & 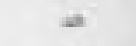 & ax & $u$ & $\mathbf{x}$ & - & wa & Lax & 4 & a.s & $w$ & 는 \\
\hline & s & $1+4 / 4+12$ & 7 & x & $a$ & 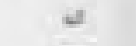 & a & " & $a$ & - & as & wat, & 4 & an. & a & 64tal \\
\hline \multirow[t]{2}{*}{+} & 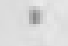 & $k+2$ & + & 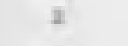 & $w$ & $x$ & $x$ & s & 4 & * & LT $T$ & $37+$ & * & 19 & ats & wat \\
\hline & $s$ & $32 / 3$ & * & + & I & 23 & $z$ & it & a & + & 13 & 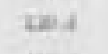 & , & 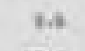 & $=$ & $\operatorname{sen}$ \\
\hline \multirow[t]{2}{*}{, } & 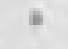 & Whe & 5 & 1 & is & 4 & $y$ & a & s. & - & महत & Les.t & 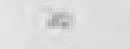 & and & an & atsivi \\
\hline & $r$ & watt & 4 & 4 & ail & $\pi$ & 4) & $w$ & 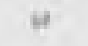 & , & $m$ & $16 \mathrm{~s}, 7$ & 11 & IEA & * & $f(x)$ \\
\hline \multirow[t]{3}{*}{, } & 4 & $1-3 / 4$ & a & 1 & 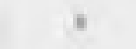 & In & vit & n & $n$ & is & IV. & inik & * & Iox & $a$ & $\rightarrow(4)$ \\
\hline & 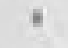 & $w+4 h$ & $=$ & v & 3 & in & ii & $n$ & 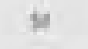 & n & 19. & ing. & 4 & Whi & ch & $(x)+(6)$ \\
\hline & t & $1 / / 2-1$ & 0 & it & , & 2 & $\Rightarrow$ & it & $\pi$ & as & D. & wis. 0 & + & HA & cs & $\rightarrow(14)$ \\
\hline \multirow[t]{2}{*}{$\uparrow$} & * & $M-4 \omega$ & c & 1 & , & 12 & म & 3 & th & $x$ & ins & Ba & u & $17=$ & 4 & $-\rightarrow-1+13)$ \\
\hline & 5 & $12 / 4+2+3$ & 7 & t & , & 13 & a & k & $\geqslant$ & Ith & Hit & His-1 & * & 2,7 & 4 & matal \\
\hline \multirow[t]{3}{*}{, } & $h$ & $3 / 6-3 \times 6$ & $=$ & * & $y$ & 4 & $=$ & is & is & 3 & B. & 6.6 & 1 & De. & $\boldsymbol{x}$ & 6idain \\
\hline & as & +124 & $z$ & 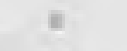 & 2 & 4 & $a$ & $\theta$ & $y$ & b & 14.4 & an, & * & 6.3. & $=$ & acasi: \\
\hline & c & bas & $=$ & n & $z$ & 2 & - & " & $s$ & 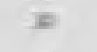 & 24. & its & , & $\Leftrightarrow$ & $a$ & 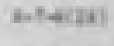 \\
\hline \multirow[t]{3}{*}{ 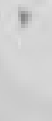 } & 3 & hal & I & $i$ & $*$ & a & * & w & 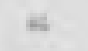 & - & It & ias & $\Rightarrow$ & $=4$ & 3 & besal \\
\hline & 4 & Not & a & in & 4 & $=$ & $>$ & 4 & at & \pm & us. & exsen & $=$ & ax. & $=$ & art \\
\hline & F & $=264$ & $x$ & 2 & " & 24 & $F$ & $=$ & 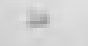 & y & 1.t. & 2as & 7 & $m$ & $\leqslant$ & -4 \\
\hline
\end{tabular}


Dille Haskeliati.

x

\begin{tabular}{|c|c|c|c|c|c|c|c|c|c|c|c|c|c|c|c|c|}
\hline in & man- & $\frac{i=1}{n .}$ & 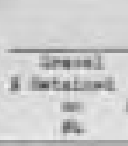 & 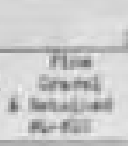 & 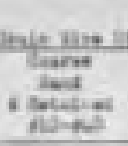 & 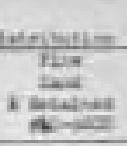 & 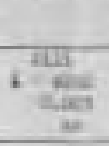 & 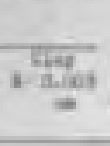 & $\frac{4+a i d}{4}$ & 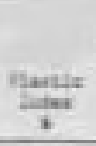 & 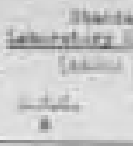 & 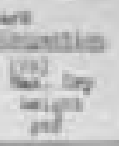 & las & 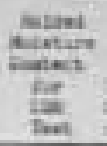 & 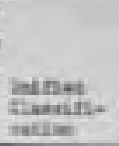 & 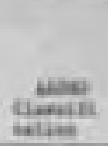 \\
\hline \multirow[t]{3}{*}{$=$} & 4 & at: & it & 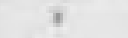 & at & $=$ & 4 & 4 & ar & - & ya & tus.s & & & a & Malay \\
\hline & 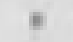 & ina & F? & at & $n$ & $a$ & 4 & is & $a$ & 7 & Ihes & arat & & & ans & mak \\
\hline & 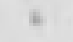 & 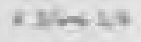 & le & + & $H$ & at & * & 1 & 4 & - & 139 & wats? & & & $a$ & $m=12$ \\
\hline \multirow[t]{3}{*}{ zi } & 4 & bats. & a & $*$ & is & $\rightarrow$ & $a$ & ta & $=$ & $t$ & $10+$ & ats & $*$ & at. & $x=$ & $\log$ \\
\hline & s & 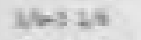 & 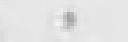 & * & $a$ & kn & Ex & $a$ & w & $z$ & tated & Iant & F & Lea & $=$ & wat \\
\hline & $x$ & $a+x+1=$ & 23 & $y$ & $z$ & z & 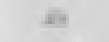 & U. & 46 & - & $-2 x$ & esta & a & tht & $m$ & nay \\
\hline \multirow[t]{2}{*}{$y$} & in & shat 45 & 2 & i & a & $x$ & $w$ & $x$ & as & 2 & Das & mest & 7 & 12:3 & $\pi$ & dela \\
\hline & + & 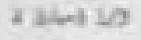 & 3 & $y$ & An & $a$ & $3=$ & in & $=$ & $*$ & ist & abs: & u & $=3$ & a. & talal \\
\hline \multirow[t]{3}{*}{ a) } & $\pi$ & -4 & 2 & t & ar & 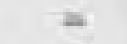 & 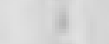 & a & $m$ & $*$ & trit & $=1$. & 8 & H:t & $a$ & $+4 \mid x i$ \\
\hline & 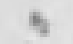 & $1+449$ & x & $y$ & 4 & is & +4 & 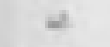 & $x$ & we & tes. & $\sin x$ & \& & is,t & a & matis \\
\hline & 1 & $14 / 2019$ & z & e & 8 & ta & a & w & \& & $F$ & Hit & ate & + & Het & 4 & $4-47$ \\
\hline \multirow[t]{3}{*}{ H } & 4 & $2 / 2-1 / 2$ & i & $y$ & 45 & 4 & $\mathrm{z}$ & $u$ & at & + & 124 & 1,4 is & & & at & todethin| \\
\hline & $t$ & $k e$ & $y$ & ) & is & as & $=$ & 4 & 6 & $t$ & 34 & bisis & 2 & 4,6 & anes & $+4 a i$ \\
\hline & i & $\rightarrow 3$ & $x$ & ik & x & is & + & + & it & - & atsot & that & & & $n-i n$ & $-4-4 \mid 0 i$ \\
\hline \multirow[t]{4}{*}{ is } & 4 & 0.1 & a & $x$ & H & ar & at & ia & $n$ & 7 & BHet & 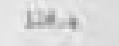 & 4 & 3.2 & abes & $+4 \mid \omega$ \\
\hline & 4 & 1 Whet & 1 & , & is & $y$ & it & bi & $\mathrm{nt}$ & - & his & He) & w) & 3.6. & a & sal-asti \\
\hline & 4 & $+1 / 4+1 / 2$ & 11 & ) & 27 & a & s & b & it & - & inter & $\mathbf{H 4}$ & $n$ & wa,? & an & $6+4(2)$ \\
\hline & 8 & $3 \mathrm{~L} / \mathrm{n}+\mathrm{L}$ & $s$ & i & 3 & iv & it & s & 16 & - & te. & $13+$. & a) & 9,7 & x-4n & Atabily \\
\hline \multirow[t]{4}{*}{ is } & 4 & $6 / 4$ & $z$ & $x$ & a) & 4 & at & wa & it & - & 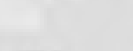 & & & & 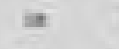 & maing \\
\hline & 4 & $2+4.2$ & 2 & 3 & 4 & 亲 & L. & in & is & - & 怙? & Whi & , & $x=$ & $a$ & atales \\
\hline & 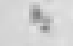 & $a 25-3 a n$ & i & 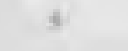 & is & ta & 3 & L & it & - & 19 & Was.s & 4 & k. & a & dragal \\
\hline & 3 & 3200 & $\mathrm{z}$ & $y$ & z & t & $=$ & $\pi$ & $a$ & 7 & 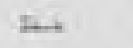 & $\tan \theta$ & + & Dis & E-s. & anf \\
\hline \multirow[t]{3}{*}{17} & 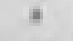 & 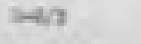 & 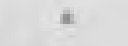 & t & 13 & 4 & 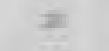 & $w$ & $=$ & $\boldsymbol{\nu}$ & Iex & anis & ) & 2,2 & $\mathbf{k}$ & +40 \\
\hline & 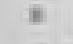 & Wh te & \pm & w & a & $\geq$ & $2 \pi$ & 14 & \pm & - & and & $2+-3$ & & & a & teatsy \\
\hline & 6 & $3 k=6 \%$ & a & 4 & $\mathbf{x}$ & at & $*$ & * & 4 & - & $t a$ & twin & & & $h=$ & 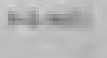 \\
\hline
\end{tabular}




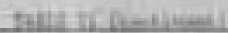

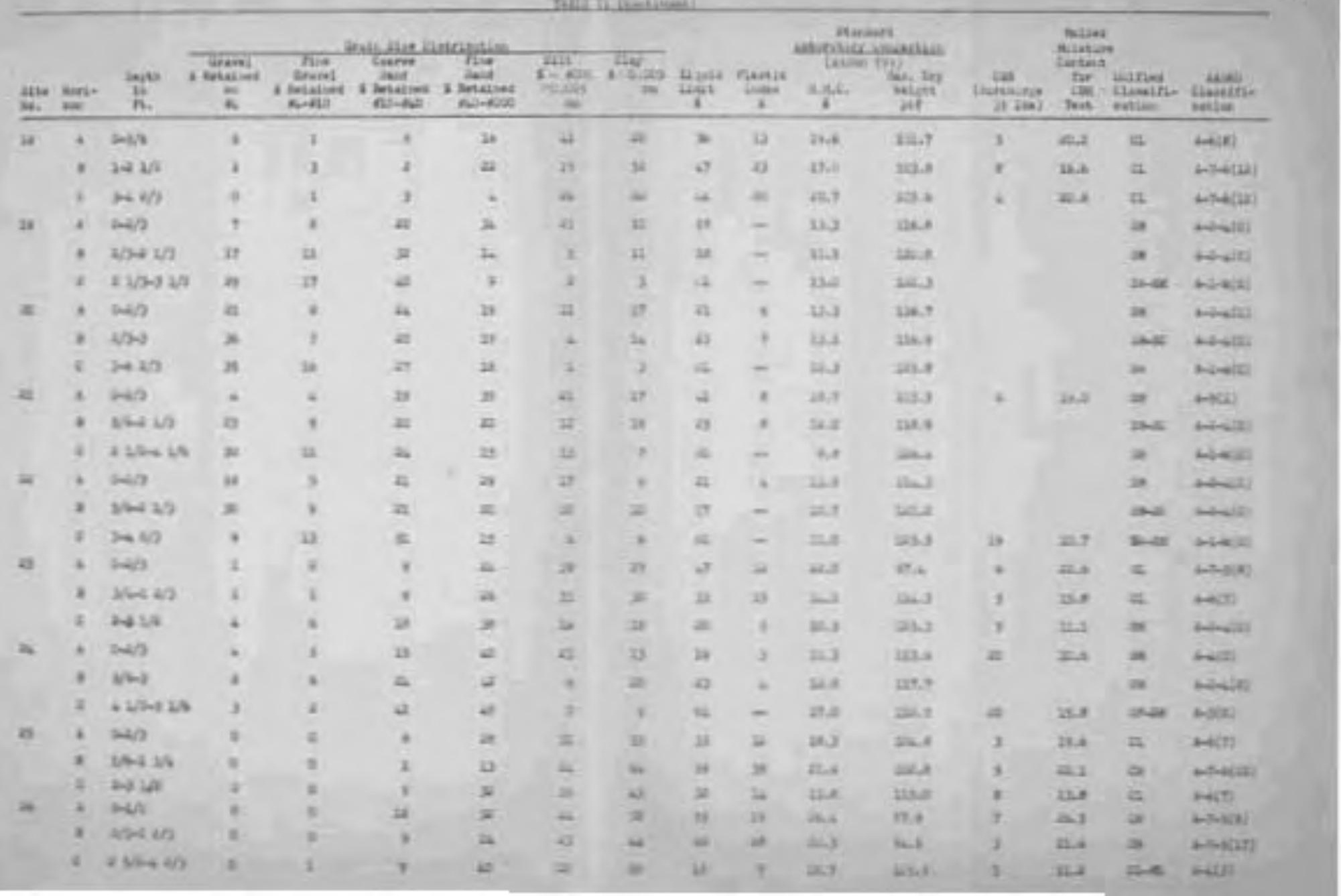




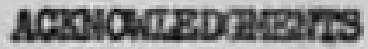

The author whes to ackmordodze the assiotenes given ty all thoso persone who have helped in the proparation of thal report. Speosal aclonondodgants are tue to mabers of the Boend for thels eotive intervert

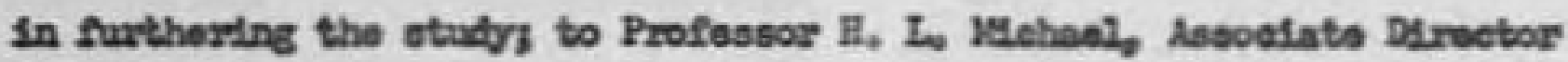

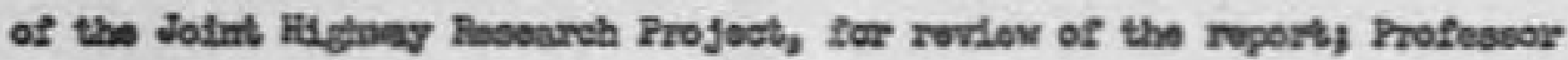

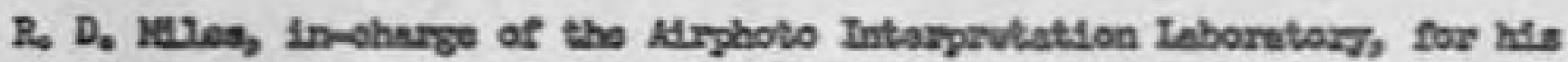
rovien and suggeotiones Profeseor Z, J. Ioder, in-churge of the Soll Teating Laboratory, for his affort in stpervlalng the eofl testings How I. Co Bass, State Soll Solentist, for his efforte In Identifying the

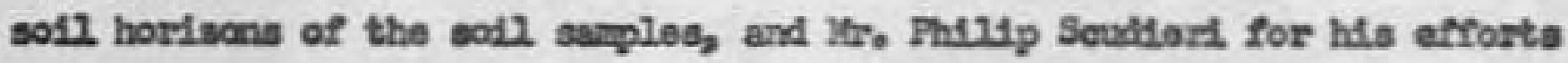
in sarple colleotlon,

All afrghotos ueed in connaotion vdth the preperation of this roport automatiealy carriod the folloring oredit Linos Fhotogrephed for Comudity Stablistation Sorvice, Porformance and Aorisl Photogruphy Diviaton, U.S.D.A. 
$J H R P-62 / 27$ 


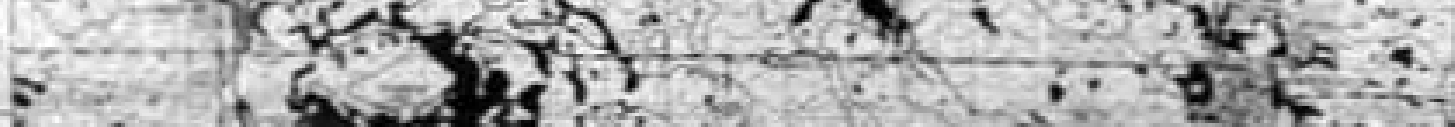

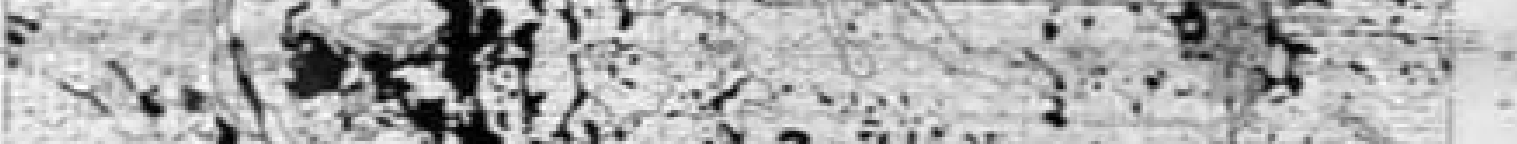




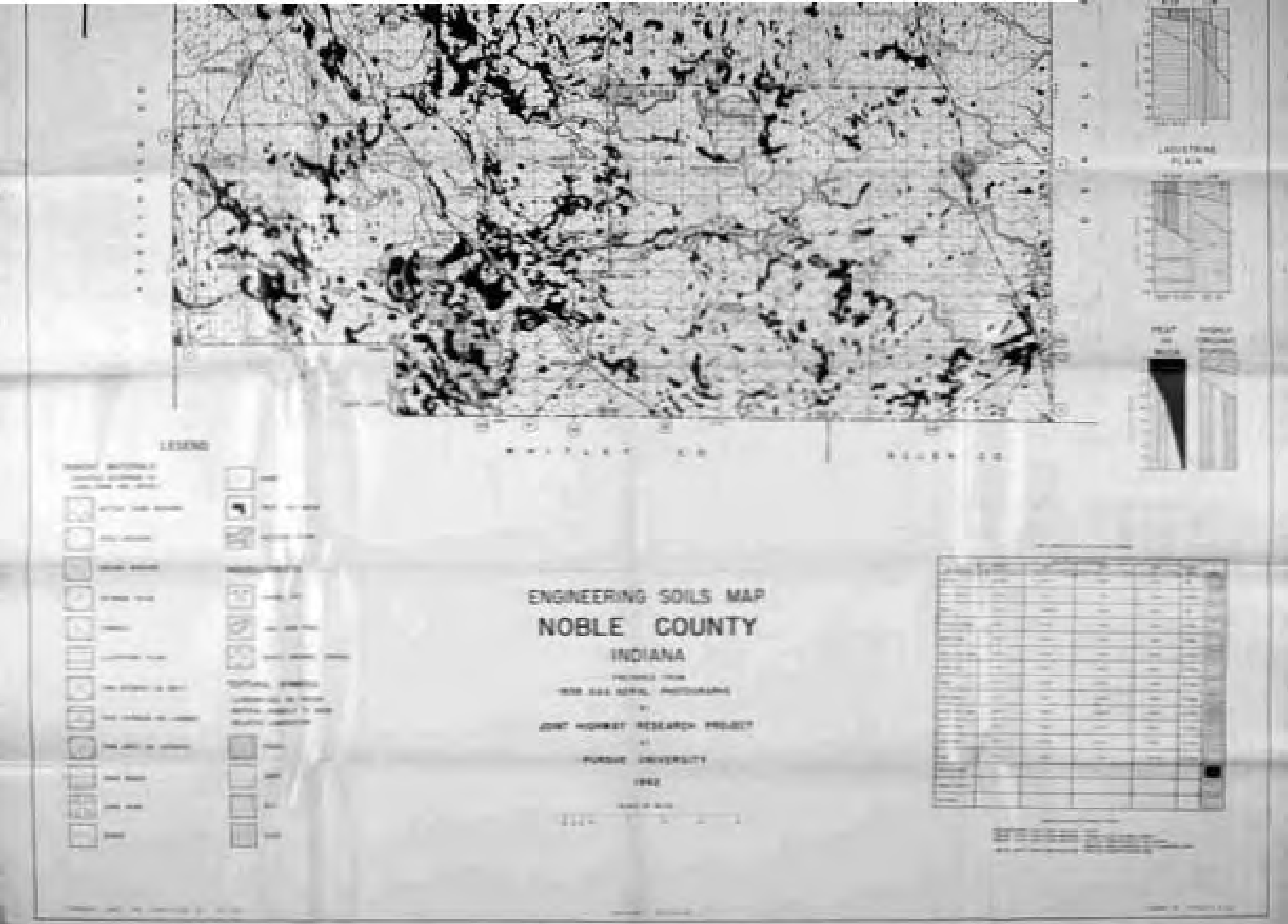

